\title{
Political Budget Cycles: The Case of Gabon
}

\author{
Jean-Jacques Tony Ekomie ${ }^{1,2} \&$ Assoumou Ondo ${ }^{1}$ \\ ${ }^{1}$ CIREGED- Omar BONGO University, Gabon \\ ${ }^{2}$ Researcher affiliated with KEDGE BS Bordeaux, France \\ Correspondence: Assoumou Ondo, CIREGED- Omar BONGO University, Gabon.
}

Received: May 18, 2019

doi:10.5430/rwe.v10n1p31
Accepted: June 6, 2019

Online Published: June 9, 2019

URL: https://doi.org/10.5430/rwe.v10n1p31

\begin{abstract}
This article analyzes the political-fiscal cycle in Gabon. In Africa, it seems that the analysis of the politico-fiscal cycle has not attracted much interest. This is particularly the case in Gabon, a small country of the Economic and Monetary Community of Central Africa (EMCCA). Unlike approaches based on the estimation of a single model linking the electoral cycle and a dimension of the state budget, we estimate four models each incorporating a different dimension of the state budget, namely: capital expenditures, total expenditures and the budget deficit. The estimation of a VAR Model (2) and three Error Correction Vector Models (ECVM) confirms the existence of an "opportunistic" politico-budgetary cycle in Gabon.
\end{abstract}

Keywords: political budget cycles, public expenditure composition

Classification JEL: D72; E62.

\section{Introduction}

Interest in politico-fiscal cycles, understood as the study of the links between political elections and fiscal policies, is gaining momentum thanks to the role given to institutional rules and constraints in the conduct of political economy. Indeed, this question is the subject of abundant theoretical and empirical developments in recent decades.

Concerning first the theoretical plan, the discussions crystallize around two main approaches: the so-called opportunist approach, initiated by Nordhaus (1975) and extended by Lindbeck (1976), who argues that re-election is the main motivation of decision-makers the Downs, 1957), on the one hand, the "partisan" approach of the politico-fiscal cycle, developed around the pioneering work of Hibbs (1976), which considers, for its part, that the influence of the electoral cycle on the budget depends on the ideological belonging of politicians (Sakurai and Menezes-Filho, 2011), on the other hand.

As for the empirical plan, several studies attempt to identify the political-budgetary cycle. This research is particularly abundant and varied in developed countries (Akhmedov and Zhuravskaya 2004, Milani 2007, Vergne 2009, Drazen and Eslava 2010).

In Africa, it seems that the analysis of the politico-fiscal cycle has not attracted much interest. This is particularly the case in Gabon, a small member country of the Economic and Monetary Community of Central Africa (EMCCA). The study of the politico-fiscal cycle is of interest for at least two reasons: firstly, Gabon's fiscal policy, which is the only instrument available to national authorities to achieve a goal of a full-employment internal balance, is governed by criteria of convergence and control of public finances.

Second, the political life of Gabon has undergone many changes. Indeed, after a period of political pluralism (1961-1968), marked by the organization of free elections, the country experienced a period of political life dominated by a single party (1968-1990) before the rehabilitation of democracy in 1990, the liberalization of political rights came from the East after the collapse of the Berlin Wall and spread to the African continent. Thus, since 1990 to date, Gabon's political life is punctuated by the organization, at the relatively regular deadline, of various presidential, legislative and municipal elections.

The present reflection is a contribution to the study of the politico-budgetary cycles in Gabon in that it estimates four dynamic models in order to determine the influence of the electoral periods on different dimensions of the State budget, namely the expenditures in capital, total expenditure, current expenditure and budget deficit. The rest of the study is organized as follows: Section 2 reviews the literature review. Section 3 presents the model of identification of the politico-fiscal cycle. Section 4 is devoted to empirical analysis. Finally, section 5 concludes. 


\section{The Literature Review}

The theoretical literature on the politico-fiscal cycle distinguishes the opportunist approach, on the one hand, the partisan approach, on the other. The opportunistic approach of the politico-fiscal cycle can be broken down into two versions: the first considers that voters reward governments for favorable economic conditions before the electoral period, without taking into account past variations in the economy or post-election slowdowns future of these expansionist policies (Lewis-Beck, 1988). These adaptive expectations of voters allow an "inflation-unemployment" arbitration that reinforces the opportunistic behavior of political decision-makers. It thus appears that the variations in the state budget are mainly due to the desire of political decision makers to seek a future mandate. This idea is echoed by Tufte (1976) and Madsen (1980), when they show that policy makers are overly using state resources to increase the probability of staying in power, in line with voters preferences for a favorable situation of the economy. The second version of the opportunistic approach, highlighted by Rogoff and Silbert (1988), Rogoff (1990), suggests that voters make rational expectations (Rogoff, 1987). Under this assumption, no "inflation-unemployment" arbitrage is possible, either in the short term or in the long term. Voters perfectly anticipate economic policies and punish politicians manipulators of the state budget for electoral purposes. From this point of view, the competence of the political decision-maker is solely determined by his ability to pursue lean budget policies (Rogoff and Sibert 1988, Rogoff 1990), to promote growth without inflation (Persson and Tabellini, 1990) or to protect economy in the face of random shocks (Cukierman and Meltzer, 1990). For Rogoff and Sibert (1988), Rogoff (1990), the government can increase its probability of staying in power by proving that it can meet the needs of the citizen at a lower cost. In addition, Persson and Tabellini (1990) argue that even with rational voters, it is possible to manipulate inflation and growth during an election period. The partisan approach is also divided into two versions: the first version, developed by Hibbs (1977), is based on the adaptive expectations of voters and the dichotomous analysis of the ruling parties (Left and Right, Republicans and Democrats). For the author, policymakers pursue macroeconomic objectives according to their partisan preferences. The existence of partisan cycles is reflected in a change in public policy following the election. The second, more recent, version is built around the pioneering work of Alesina (1987 and 1988), which admits that with rational expectations, only surprise inflation affects yields, and the size of the cycle depends on the degree of electoral uncertainty.

The recent analyzes (Golten and Poterba, 1980; and Stein, 1982, Beauvallet, 2008) argue that, for a government, the macroeconomic variables (GDP, unemployment, inflation, etc.) are more complex to manipulate than budget variables. Which explains why political budget cycle are more frequent than political economy cycle. Regarding this last aspect, for Hagen (2006), Milani (2007), Streb and Torrens (2009), Vicente, Rios and Guillamon (2012), Ebeke and Olser (2013), Bonfatti and Forni (2017), the study of politico-budgetary cycles must be able to take into account the rules (fiscal and fiscal rules) and institutional constraints. Whether by opportunism or ideology,

On an empirical level, interested in the existence of politico-fiscal cycles in Russian municipalities, Akhmedov and Zhuravskaya (2004) study a panel of local political jurisdictions and show that municipalities increase public spending before and after elections. just after their reelections. Which causes a deficit during the election year. On the other hand, the authors do not provide evidence of changes in local taxation before or after the voting period, which confirms the existence of opportunistic political-budgetary cycles in these localities. In the case of the United States, Milani (2007) points out that the existence of partisan cycles in tax policies may differ depending on whether the President of the Union is Democrat or Republican. In this respect, it shows that the application of fiscal policy depends on the ideological lineage of the President of the Republic

For its part, Vergne (2009) studies the nature of public expenditures in relation to the election periods. To this end, he argues that public spending is moving towards more visible current spending, particularly wages and subsidies, and capital expenditures. In the same vein, Drazen and Eslava (2010) show that public spending increases before the elections, including the construction of roads, power stations and hydro. On the other hand, interest payments, retiree transfers and temporary worker payments fall during the election years.

In a study focusing on the case of Croatia, Mackic (2014) shows that the budget deficit and total expenditure decrease because of the institutional context which limits the manipulation of the budget at the local level. The results of Mackic (2014) lead to the rejection of the existence of an opportunistic cycle in Croatian municipalities. For the author indeed, to ensure the re-election of local elected representatives, municipalities circumvent the institutional constraint of the local budget by resorting to public borrowing and private companies that provide public services. More recently, Bonfatti and Forni (2017), in the case of Italy, show that the impact of the opportunistic cycle is higher on capital expenditures and increases during the election years, as well as two years before and after the elections. 
Taking into account the rules (fiscal and / or fiscal) and institutional constraints, Rose (2006) argues that in the United States balanced fiscal rules help to curb political cycles in overall spending, taxes and deficits. In the presence of budgetary rules, the manipulation of the budget is considerably reduced during the election period. Similarly, according to Alt and Rose (2007), fiscal stability rules are associated with a smaller increase in spending as the election deadline approaches. This has the effect of reducing the public deficit. In Europe, Hagen (2006) provides evidence that the influence of electoral cycles on fiscal and fiscal policy instruments is reduced by the Maastricht Treaty between 1992 and 1998 in the municipalities of the countries of the European Union (EU) where no manipulation is observed. Garcia-Sanchez et al. (2011) have similar results since they argue that the handling of the debt in the run-up to the elections has decreased significantly since the introduction of the budget stability law. This view is also shared by Streb and Torrens (2009) who show that fiscal rules limit electoral cycles on debt.

While for Vicente, Rios and Guillamon (2012) the budget stability law avoids the influence of electoral cycles on debt, it does not, however, lessen the incentives of policy makers to manipulate the deficit, capital expenditure and current expenditure. . In the same vein, Grembi, Troiano and Nannicini (2011) show that the domestic stability pact reduces spending on average and improves fiscal discipline, although spending is higher during pre-electoral periods.

In developing countries, Sakurai and Menezes-Filho (2011) study the politico-fiscal cycle in "young democracies" where voters are less experienced. In addition, the authors note that the manipulation of fiscal policies is greater than in the old democracies. In this regard, they observe that Brazilian municipal deficits increase during the election years. Total and current expenditures are increasing and local revenues are decreasing. By limiting their analysis to the period 1989-2005, the authors also show that partisan ideology exerts a relatively strong influence on the performance of local public accounts. These results thus confirm the existence of partisan cycles in the management of municipal budgets. Expenditures, revenues and fiscal balance behave differently depending on the electoral cycle and the ideology of the party of mayors. In the same vein, Ebeke and Ölçer (2013) argue that several tax indicators are used to assess the extent of electoral cycles on the budget. For these authors, it is essential to break down the tax indicators to better understand the influence of electoral cycles on government policies. Drawing on low-income countries, Ebeke and Ölçer (2013) show that public consumption expenditure increases during the election year, with no significant decrease two years after the elections; while public investment, as a percentage of GDP, declines by almost 0.4 percentage points the year after the election. The authors' results thus confirm the influence of an opportunistic electoral cycle on the management of public expenditures.

\section{The Identification Model of the Politico-Budgetary Cycle}

To identify the politico-fiscal cycle, we first analyze the evolution of public expenditure in relation to the election periods. We then perform an econometric application.

\subsection{Evolution of Public Expenditures and Election Periods}

The evolution of total public expenditure can be visualized on two graphs intersecting the different electoral periods that have punctuated the political life of Gabon since the early 1980s.

For this purpose, Graph 1 presents the evolution of total public expenditure before, during and after the presidential elections of the single party period (1983-1990).

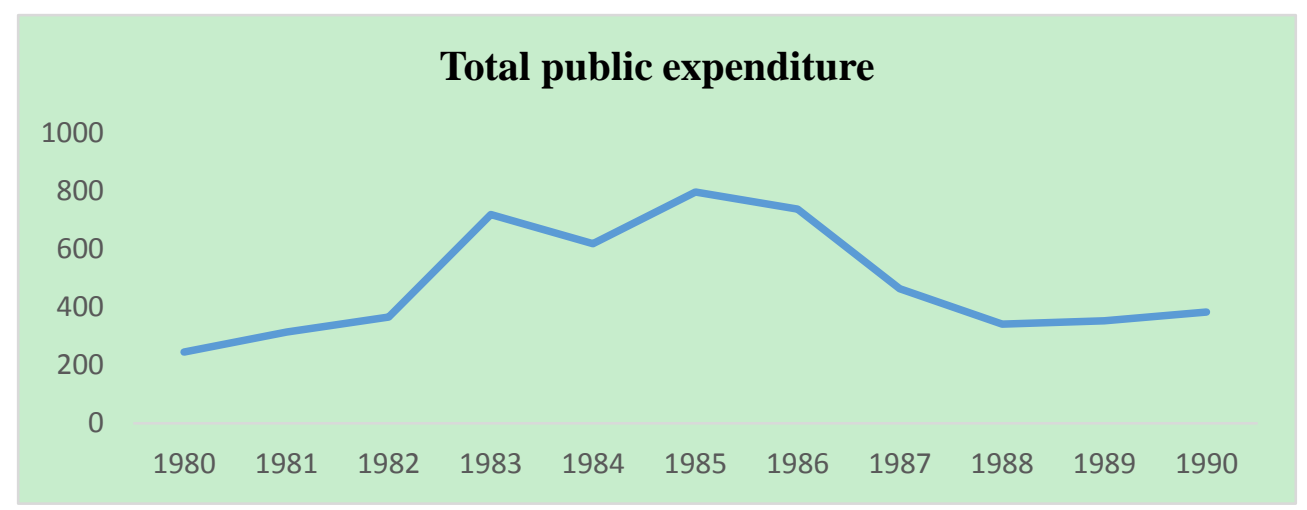

Graph 1. Total public expenditure in the single party period 
Graph 1 shows that total public expenditure increased in 1982, one year before the presidential elections. They peaked in 1983 during the election year, and ended up falling sharply the following year. The presidential elections of 1988 take place in a context of economic crisis following the collapse of the price of a barrel of oil (which goes from $\$ 28$ in December 1985 to $\$ 10$ from February 1986), accentuated by the depreciation of the French franc (to which the FCFA was attached at the time) in relation to the dollar. Thus, the fiscal policy implemented with the support of the International Monetary Fund leads to a significant reduction in public expenditures as early as the year 1987. For the 1988 financial year, there is a less significant decline in public expenditure, probably because of the organization of presidential elections.

Graph 2 shows the evolution of total public expenditure in different phases of the elections since the return to political pluralism to the present day.

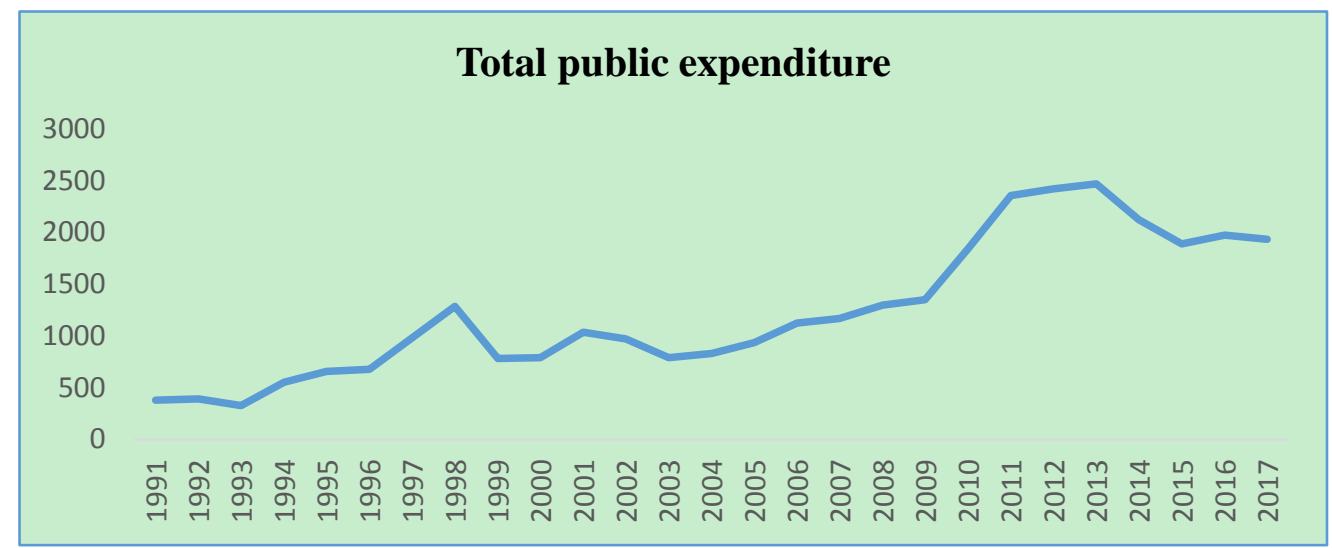

Graph 2. Total public expenditure in the multiparty period

It can be seen from Graph 2 that during the 1993 presidential election, state spending, already slightly up since 1991, increased sharply from 1993 to 1994. In addition, the trend in public spending from 1996 to 1999, is characterized by three phases: between 1996 and the middle of 1997, there is an expansion of total public expenditure. From 1997 to the middle of 1998, stagnation of total public expenditure was recorded, which was followed by a significant decline after the second half of 1998. Likewise, the organization of the legislative elections the beginning of the 2000s highlights two phases in the evolution of public expenditure: from 2000 to 2001, there was a phase of expansion of total public expenditure which peaked in 2001, the year of parliamentary elections. Spending then dropped sharply between 2001 and 2002, after the electoral phase. In the mid-2000s, total public spending also increased from 2004, a year before the 2005 presidential elections. They continue to grow after the elections, reaching a peak in the parliamentary elections the following year. It is only after the election year in 2006 that spending will stagnate slightly until 2007. At the beginning of the decade 2010, the evolution of the public expenditure curve is marked by a trend towards high corresponding to a peak in the parliamentary elections held in 2011. In contrast, the year of the 2009 presidential elections is marked by a stagnation in the evolution of total public expenditure. Two main reasons can be mentioned in this regard: the wait-and-see context linked to the death of President Omar BONGO ONDIMBA, on the one hand, the anticipated organization of the presidential elections in August this year. Finally, after reaching a low in 2014, caused by the fall in the price of a barrel of oil, total public expenditure increased in 2015 to reach a peak in 2016, the year of the presidential elections. Subsequently, they gradually decrease until 2017.

In total, Graphs 1 and 2 show that total public spending tends to increase one year before elections (legislative or presidential) to peak during the election year. Then, they drop significantly after the elections. It also seems that the "electoral surprise" of 2009 (early presidential elections) does not give rise to an increase in total public expenditure.

\subsection{Presentation of the Model}

We build on Mackic's (2013) dynamic model, which aims to verify the existence of the politico-fiscal cycle in municipalities. In this respect, the equation of the model is formulated as follows: 


$$
\mathrm{Y}_{\mathrm{t}}=\mu+\gamma \mathrm{Y}_{\mathrm{t}-1}+\beta_{1} \mathrm{X}_{1, \mathrm{t}}+\beta_{2} \mathrm{X}_{2, \mathrm{t}}+\cdots+\beta_{\mathrm{k}} \mathrm{X}_{\mathrm{k}, \mathrm{t}}+\epsilon_{\mathrm{t}}
$$

For $\mathrm{t}=1,2, \ldots, \mathrm{T}$

With:

- $\quad Y_{t}$, the dependent variable ;

- $\quad \mathrm{Y}_{\mathrm{t}-1}$, the delayed dependent variable ;

- $\quad \mathrm{X}_{\mathrm{k}, \mathrm{t}}$; the $\mathrm{k}$ independent variables ;

- $\quad \beta_{1} \ldots \beta_{\mathrm{k}}$, the parameters of the exogenous variables;

- $\epsilon_{\mathrm{t}}$, le the error term.

Like Mackic (2013), we retain four (4) specifications of equation [1] according to the four (4) dependent variables that represent the different dimensions of public expenditure, namely current expenditures, in capital (Rogoff, 1990, Vergne, 2006, Ehrhart, 2012), total expenditures (Nordhaus, 1975, Tufte, 1978, Rogoff and Sibert, 1988), and the budget deficit (Nordhaus, 1975, Tufte, 1978, Rogoff and Sibert, 1988). ). Four exogenous variables are also selected, including an "election" interest variable and three control variables: real GDP per capita (Dubois, 2006), the inflation rate (Dubois, 2006) and the real interest rate. (Mackic, 2014)

By integrating the exogenous variables in the model [1], we obtain the following relation:

$$
Y_{t}=\mu+\gamma Y_{t-1}+\beta_{1} e e_{t}+\beta_{2} \text { inf }_{t}+\beta_{3} \text { pib }_{t}+\beta_{4} \mathrm{tir}_{\mathrm{t}}+\epsilon_{\mathrm{t}}
$$

For $\mathrm{t}=1,2, \ldots, \mathrm{T}$

With:

- $\quad Y_{t}$, the dependent budget variable;

- $\quad \mathrm{Y}_{\mathrm{t}-1}$, the delayed dependent variable ;

- $\quad$ ele $_{\mathrm{t}}$, election period ;

- $\quad$ inf $_{\mathrm{t}}$, rate of inflation;

- $\quad$ pib $_{\mathrm{t}}$, Gross Domestic Product ;

- $\quad$ tir $_{\mathrm{t}}$, real interest rate of banks;

- $\epsilon_{\mathrm{t}}$, the error term.

We estimate the following four models:

$$
\begin{aligned}
\mathrm{dc}_{\mathrm{t}} & =\mu+\gamma \mathrm{dc}_{\mathrm{t}-1}+\beta_{1} \mathrm{ele}_{\mathrm{t}}+\beta_{2} \mathrm{inf}_{\mathrm{t}}+\beta_{3} \mathrm{pib}_{\mathrm{t}}+\beta_{4} \mathrm{tir}_{\mathrm{t}}+\epsilon_{\mathrm{t}} \\
\operatorname{inv}_{\mathrm{t}} & =\mu+\gamma \operatorname{inv}_{\mathrm{t}-1}+\beta_{1} \mathrm{ele}_{\mathrm{t}}+\beta_{2} \mathrm{inf}_{\mathrm{t}}+\beta_{3} \mathrm{pib}_{\mathrm{t}}+\beta_{4} \mathrm{tir}_{\mathrm{t}}+\epsilon_{\mathrm{t}} \\
\mathrm{dt}_{\mathrm{t}} & =\mu+\gamma \mathrm{dt}_{\mathrm{t}-1}+\beta_{1} \mathrm{ele}_{\mathrm{t}}+\beta_{2} \mathrm{inf}_{\mathrm{t}}+\beta_{3} \mathrm{pib}_{\mathrm{t}}+\beta_{4} \mathrm{tir}_{\mathrm{t}}+\epsilon_{\mathrm{t}} \\
\mathrm{def}_{\mathrm{t}} & =\mu+\gamma \mathrm{def}_{\mathrm{t}-1}+\beta_{1} \mathrm{ele}_{\mathrm{t}}+\beta_{2} \mathrm{inf}_{\mathrm{t}}+\beta_{3} \mathrm{pib}_{\mathrm{t}}+\beta_{4} \mathrm{tir}_{\mathrm{t}}+\epsilon_{\mathrm{t}}
\end{aligned}
$$

For $\mathrm{t}=1,2, \ldots, \mathrm{T}$

With:

- $\mathrm{dc}_{\mathrm{t}}$, current expenditure;

- $\quad$ inv $_{\mathrm{t}}$, capital expenditure;

- $\mathrm{dt}_{\mathrm{t}}$, total expenses;

- $\quad$ def $_{\mathrm{t}}$, budget deficit;

- $\quad$ ele $_{\mathrm{t}}$, election period;

- $\quad$ inf $_{\mathrm{t}}$, rate of inflation;

- $\quad$ pib $_{\mathrm{t}}$, Gross Domestic Product;

- $\quad \operatorname{tir}_{\mathrm{t}}$, real interest rate of banks;

- $\epsilon_{\mathrm{t}}$, the error term.

We consider that if politicians adopt opportunistic behavior, the following phenomena could be verified in the facts: i) expenditures are up in the year of the election or the year before; (ii) expenditures increase faster in the year of the 
election or the year before than in other years; (iii) expenditures during these two years are decreasing at a lower rate than in previous years.

On the other hand, if they engage in partisan behavior such that they attempt to manipulate public policy instruments after the election has passed, the following observations could be made: (i) spending increases in the following year election; (ii) spending increases faster in the year after the election than in other years; (iii) post election expenses decrease at a lower rate than other years.

\section{Empirical Analysis}

The data used come from the Scoreboard of the Gabonese economy over the period 1980-2017 (38 years). These are public capital expenditures $\left(\operatorname{inv}_{t}\right)$, total expenditures $\left(\mathrm{dt}_{t}\right)$, current $\left(\mathrm{dc}_{\mathrm{t}}\right)$, budget deficit $\left(\operatorname{def}_{\mathrm{t}}\right)$, inflation rate $\left(\inf _{\mathrm{t}}\right)$, gross domestic product $\left(\mathrm{pib}_{\mathrm{t}}\right.$, ) and rate of real interest $\left(\mathrm{tir}_{\mathrm{t}}\right)$. For the sake of the harmonization of quantities, all these variables have been linearized by the natural logarithm (ln). In addition, trends in the different dimensions of public spending are determined using the Hodrik and Prescott (HP) filter. The "election" is the variable of interest relative to the study of the politico-budgetary cycles. In most cases, the variable "election" $\left(\mathrm{ele}_{\mathrm{t}}\right)$ is studied and broken down into three phases, namely a pre-electoral phase, an electoral phase and a post-election phase. This variable takes the value 0 or 1 in each case depending on whether or not it is the study period. Thus, we will consider this decomposition of the variable election to remain in the logic of the electoral cycle of Mackic (2013).

To analyze the effects of the elections on the budget of the Gabonese State, we resort to the developments of vector models with error correction. The estimation of dynamic models is done by the method of Johansen (1988), using the software Eviews8.

Two tests of stationarity are performed on the variables (level or differences). The Dickey-Fuller Augmented (ADF) test which considers the absence of a structural break under the alternative hypothesis and that of Phillips-Perron (Pperron), built on the assumption of a trend break with a known date. The results of said tests can be viewed in Table 1 below.

Table 1. Stationnarity tests ADF et Pperron

\begin{tabular}{|c|c|c|c|c|}
\hline \multirow{4}{*}{ variables } & \multicolumn{2}{|c|}{ ADF Test } & \multicolumn{2}{|c|}{ Pperron Test } \\
\hline & & First & & \\
\hline & Level & Difference & Level & First Difference \\
\hline & Pvalue & Pvalue & Pvalue & Pvalue \\
\hline $\mathrm{c}_{-} \mathrm{dc}_{\mathrm{t}}$ & 0.0006 (none) & --- & 0.0005 (none) & --- \\
\hline c_inv $_{\mathrm{t}}$ & 0.0001 (none) & --- & 0.0058 (none) & --- \\
\hline $\mathrm{c}_{-} \mathrm{dt}_{\mathrm{t}}$ & 0.0008 (none) & --- & 0.0035 (none) & --- \\
\hline c_def $_{\mathrm{t}}$ & 0.0000 (none) & --- & 0.0000 (none) & --- \\
\hline $\mathrm{ele}_{\mathrm{t}}$ & $0.0000(\mathrm{c})$ & --- & 0.0000 (none) & --- \\
\hline $\inf _{\mathrm{t}}$ & 0.0001 (none) & --- & 0.0002 (none) & --- \\
\hline $\mathrm{pib}_{\mathrm{t}}$ & 0.9885 (none) & 0.0000 (none) & 0.9885 (none) & 0.0000 (none) \\
\hline $\operatorname{tir}_{\mathrm{t}}$ & $0.0026(\mathrm{c} \& \mathrm{t})$ & --- & $0.0029(\mathrm{c} \& \mathrm{t})$ & --- \\
\hline
\end{tabular}

Note: the variable is stationary when the Pvalue is less than 0.01 (at the $1 \%$ threshold), 0.05 (at the $5 \%$ threshold) and 0.10 (at the $10 \%$ threshold). The terms (c \& t), (c) and (none) respectively mean "with constant and trend", "with constant" and "without constant or trend".

Table 1 shows that the budget deficit, government spending (total, current, capital), elections, inflation rate and real interest rate are level. Only GDP is stationary in first difference at the $1 \%$ threshold. As not all series are level-integrated, it is possible to test the existence of at least one cointegration relationship between these variables for different models.

In order to determine the optimal delay number, we estimate Vector Auto Regressive (VAR) vector models for different delays. Bonfatti and Forni (2017) state that fiscal policy cycles do not exceed a two-year period before and 
after the election period. For this, we consider a delay between 0 and 2 . The optimal delay obtained for each model is that which minimizes the Akaike criterion and the Likelihood Ratio, as can be seen in Table 2.

Table 2. Optimal delay

\begin{tabular}{ccccc} 
Models & Model 1 & Model 2 & Model 3 & Model 4 \\
\hline LR & 2 & 2 & 2 & 2 \\
\hline AIC & 2 & 2 & 1 & 2
\end{tabular}

Note: The table values represent the delay number that minimizes the Akaike information criteria (AIC) and the likelihood ratio (LR).

According to Table 2, the estimation of the different models concludes that the delay which minimizes the criteria of akaike and of the likelihood ratio is of the order 2 .

We perform the Johansen (1988) cointegration test on level variables using the trace and likelihood ratio (VR) test. The results are shown in Table 3 below.

Table 3. Johansen cointégration test

\begin{tabular}{ccccc}
\hline Models & Model 1 & Model 2 & Model 3 & Model 4 \\
\hline Trace & 2 & 3 & 2 & 3 \\
\hline RV & 2 & 3 & 2 & 3
\end{tabular}

Note: The values represent the number of cointegration relationships, according to the criteria of trace and maximum likelihood

The results of these tests confirm the hypothesis that there is at least one cointegration relationship between the variables. In this respect, we first estimate an error-corrected vector model (ECVM) with a cointegration equation and 2 delays, which allows us to distinguish between long-term and short-run effects. However, the estimation of the model [1] in the form of an ECVM presents problems of autocorrelation of the residues, which led us to estimate it in the form of a VAR (2), with stationary variables. Table 4 below presents the results of the four models.

Table 4. Short term relationships

\begin{tabular}{ccccc}
\hline Modèles & Model 1 & Model 2 & Model 3 & Model 4 \\
\hline Estimation Method VAR (2) & ECMV & ECMV & ECMV \\
\hline D(ele t-1 $)$ & 4.63581 & $87.1763^{*}$ & $323.247^{*}$ & $324.3042^{*}$ \\
\hline $\mathbf{D}\left(\mathbf{e l e}_{\mathbf{t}-\mathbf{2}}\right)$ & 1.51677 & $60.0211^{*}$ & $200.601^{*}$ & $175.1240^{*}$ \\
\hline FR & - & $-0.669^{*}$ & $-0.51123^{*}$ & $-0.92662^{*}$ \\
\hline R-squared & 0.17410 & 0.805687 & 0.695350 & 0.63660 \\
\hline F-statistic & 0.50593 & 8.669605 & 5.477899 & 4.2043
\end{tabular}

Note: FR is the Recall Force (Error Correction Coefficient). F-statistic represents the Fischer statistic. When the coefficient is preceded by $(*)$ then it is significant at the $1 \%$ threshold.

The results in Table 4 show that the models [2], [3] and [4] have negative and significant return forces (FR) at the 1\% threshold, with R-squared coefficients greater than $50 \%$. With regard to the model [1], the coefficient of determination (R-squared) is $17.41 \%$ and the coefficients associated with the elections are not significant.

After estimating the models, it is now necessary to carry out a set of post-estimation tests: the autocorrelation test (LM-test) and the test of heteroscedasticity (White test) of the residues. The good quality of the ECVM estimation 
results requires that the residuals of the estimated models are not autocorrelated. The selected test is LM test whose null hypothesis is the absence of autocorrelation of the residues.

Table 5. Autocorrelation of residues (LM-stat)

\begin{tabular}{ccccc}
\hline Models & Model 1 & Model 2 & Model 3 & Model 4 \\
\hline Lags 1 & 0.0000 & 0.7539 & 0.7049 & 0.2007 \\
\hline Lag 2 & 0.0000 & 0.0425 & 0.4354 & 0.6839 \\
\hline
\end{tabular}

Note: The values in the table are the pvalue. When the coefficient is preceded by $(*)$ then the Lag is significant at the $1 \%$ threshold.

The results in Table 5 show that the pvalue of models [2], [3] and [4] are greater than 0.01 . The null hypothesis cannot be rejected at the $1 \%$ threshold. The residues of these models are not autocorrelated. On the other hand, the model [1] presenting a problem of autocorrelation of the residues, it will not be the object of interpretation.

The hypothesis of homoscedasticity requires that the variance of the residuals be constant for each observation. The test retained is that of White whose null hypothesis is the homoscedasticity of the residues.

Table 6. Heteroscedasticity of residues (White test)

\begin{tabular}{ccccc}
\hline Models & Model 1 & Model 2 & Model 3 & Model 4 \\
\hline Chi - sq & 268.4846 & 313.431 & 325.727 & 324.686 \\
\hline df & 270 & 330 & 330 & 330 \\
\hline pvalue & 0.5146 & 0.7357 & 0.5561 & 0.5722 \\
\hline
\end{tabular}

Note: When the coefficient is preceded by $(*)$ then it is significant at the $1 \%$ threshold.

The results in Table 6 show that the probabilities of rejection of the null hypothesis are all greater than $1 \%$. The null hypothesis cannot be rejected. There is homoscedasticity of the residues.

The validation of the ECVM and the VAR requires that they be stable. This stability appears when all these roots are inside the circle of diameter 1. According to the graphs in appendix 2, all the roots of VAR (2) and ECVM are inside the circle, therefore they are stable.

Moreover, the coefficients obtained from the models [2], [3] and [4] support the hypothesis according to which the pre-electoral period corresponds to a phase of increase of public expenditures of the State. In other words, the politico-fiscal cycle is of the "opportunistic" type. Indeed, two years before the election year, the elections ( $\left.\left(\mathrm{ele}_{\mathrm{t}-2}\right)\right)$ have a positive effect on total public expenditure $(200,601)$, capital expenditure $(60,021)$ and the budget deficit (175.1240). This influence increases as we get closer to the election year. One year before the election year $\left(\mathrm{D}\left(\mathrm{ele}_{\mathrm{t}-1}\right)\right)$, the influence of elections is even higher on total spending (323.24), capital expenditure (87.176) and the budget deficit. (324.30). In this, our results support the work of Bonfatti and Forni (2017), who point out that the impact of the "opportunistic" cycle is particularly high for capital expenditure and manifests itself two years before the elections.

In Gabon, the approach of the elections represents the period during which one generally observes the launching by the State of various projects (constructions of roads, hospitals, etc.). In the same way, it is noted that the regulation by the Government of the internal debt to the companies procuring public contracts is often carried out with the approach of the elections. Finally, municipal budgets, the level of endowments, grants, donations and the circulation of money are also increasing as elections approach (presidential or legislative). However, the increase in public spending during election periods is not accompanied by increased tax revenues, as the government avoids raising taxes by electioneering opportunism, which aggravates the budget deficit. In this respect, our results converge with those of Sakurai and Menezes-Filho (2011) who argue that in "young democracies", where voters are less experienced and manipulation of fiscal policies is greater, public deficits increase during election years.

\section{Conclusion}

In this article, we study the links between the cycle of fiscal policy and the elections in Gabon from Error Vector Models (ECVM) and a second-order VAR. After estimating four dynamic models, our results validate the hypothesis 
of the existence of an "opportunistic" politico-budgetary cycle in Gabon. In fact, over the period 1983-2016, Gabonese policy makers repeatedly use the country's public resources excessively to increase their probability of staying in power, convinced that voters have a clear preference for a favorable economic situation. In other words, the variations in the state budget, which are regularly observed two years or even a year before the election year, are explained by the desire of the political decision-makers to ask each time a new mandate to the electors and stay in power.

\section{References}

Akhmedov, A., \& Zhuravskaya, E. (2004). Opportunistic Political cycles: test in a young democracy. The Quarterly Journal of Economics, 119(4), 1301-1338. https://doi.org/10.1162/0033553042476206

Alesina, A. (1987). Macroeconomic policy in a two party system as a repeated game. Quarterly. Journal of Economics, 102(3), 651-678. https://doi.org/10.2307/1884222

Alt, J. E., \& Rose, S. (2007). Context-conditioned political budget cycles. In Boix, C., \& Stokes, S. C. (Eds.), Oxford handbook of comparative politics (pp. 845-867). New York, NY: Oxford University Press.

Bacache-Beauvallet, M. (2008). Les cycles politiques. Idées économiques et sociales, 1(51), 10-17. https://doi.org/10.3917/idee.151.0010

Bonfatti, A., \& Forni, L. (2017). Les règles fiscales pour dompter le cycle budgétaire politique: éléments de preuve des municipalités italiennes. IMF Working Paper.

Brown, T.A., \& Stein, A.A. (1982). The political economy of national election comparative politics, 14, 479-499. https://doi.org/10.2307/421633

Cukierman, A., \& Meltzer, A. H. (1986). A positive theory of discretionary policy. Economic Inquiry, 24, 367-388. https://doi.org/10.1111/j.1465-7295.1986.tb01817.x

Downs, A. (1957). An Economic theory of Democracy. New-York: Harper et Row.

Drazen, A., \& Eslava, M. (2010). Electoral manipulation via voter-friendly spending: Theory and evidence. Journal of Development Economics, 92(1), 39-52. https://doi.org/10.1016/j.jdeveco.2009.01.001

Dubois, E. (2006). The Political Economy of the Public Finances Situation: An Empirical Investigation with French Data, 1970-2006.

Ebeke, C., \& Ölçer, D. (2013). Fiscal Policy over the Election Cycle in Low-Income Countries 1 Fiscal Policy over the Election Cycle in Low-Income Countries. IMF Working Paper. https://doi.org/10.5089/9781475588514.001

Ehrhart, H. (2012). Elections and the structure of taxation in developing countries. Public Choice, 1-17. https://doi.org/10.2139/ssrn.2209215

Garcia-Sanchez, I., Prado-Lorenzo, J., \& Cuadrado-Ballesteros, B. (2011). Do progressive governments undertake different debt burdens? Partisan vs. electoral cycles. Revista de Contabilidad, 14(1), 29-57. https://doi.org/10.1016/S1138-4891(11)70021-8

Grembi, V., Nannicini, T., \& Troiano, U. (2011). Do Fiscal Rules Matter? A Difference-in-Discontinuities Design. Università Bocconi, mimeo. https://doi.org/10.2139/ssrn.1852523

Hagen, T. (2007). Estimating the effect of parliamentary elections on primary budget deficits in OECD countries. Economics Bulletin, 8(8), 1-5.

Hibbs, D. A. (1975). Economic Interest and the Politics of MacroeconomicPolicy (Center for International Studies. Massachusetts Institute of Technology, Cambridge, MA) Monograph C/75-14.

Hibbs, D. A. (1977). Political Parties and Macroeconomic Policy. American Political Science Review, 71, 1467-1487. https://doi.org/10.1017/S0003055400269712

Hibbs, D. A. (1987). The American Political Economy: Macroeconomics and Electoral Politics in the United States. Harvard University Press, Cambridge, MA.

Hibbs, D. A. (1992). Partisan Theory After Fifteen Years. European Journal of Political Economy, 8, 361-373. https://doi.org/10.1016/0176-2680(92)90001-W

Lewis-Beck, M. (1988). Economics and Elections. University of Michigan Press, Ann Arbor.

Lindbeck, A. (1976). Stabilization Policies in Open Economies with Endogenous Politicians. American Economic Review Papers and Proceedings, 1-19. 
Mackic. (2013). Political budget cycles at the municipal level in Croatia. Financial Theory and Practice, 38(1), 1-35. https://doi.org/10.3326/fintp.38.1.1

Madsen, H. (1980). Electoral outcomes and macroeconomic policies: the Scandinavian cases. In Whitely, P. (Ed.), Models of Political Economy (pp.15-46). Sage, London.

Milani F. (2007). Political Business Cycles in the New Keynesian Model. Working Papers 070805, University of California-Irvine, Department of Economics.

N'Zegho, D. S. (2014). démocratie et organisation des partis politiques au Gabon. halshs-00942757.

Nordhaus, W. (1975). The political business cycle. Review of Economic Studies, 42, 169-190. https://doi.org/10.2307/2296528

Persson, T., \& Tabellini, G. (1990). Politique macroéconomique, crédibilité et politique.

Rogoff, K. (1987b). Equilibrium Political Budget Cycles. (mimeo). https://doi.org/10.3386/w2428

Rogoff, K. (1990). Equilibrium Political Budget Cycles. The American Economic Review, 80(1), 21-36.

Rogoff, K., \& Sibert, A. (1988). Elections and Macroeconomic Policy Cycles. The Review of Economic Studies, 55. https://doi.org/10.2307/2297526

Rose, S. (2006). Do Fiscal Rules Dampen the Political Business Cycle?. Public Choice, 128(3), 407-431. https://doi.org/10.1007/s11127-005-9007-7

Sakurai, S., \& Menezes-Filho, N. (2008). Fiscal Policy and Reelection in Brazilian Municipalities. Public Choice, 137, 301-14. https://doi.org/10.1007/s11127-008-9329-3

Sakurai, S., \& Menezes-Filho, N. (2011). Opportunistic and partisan election cycles in Brazil: new evidence at the municipal level. Public Choice, 148, 233-247. https://doi.org/10.1007/s11127-010-9654-1

Streb, J. M., \& Torrens, G. (2009, April). Making Rules Credible: Divided Government and Political Budget Cycles. Public Choice, 156(3-4). https://doi.org/10.1007/s11127-012-9923-2

Tufte, E. (1978). Political control of the Economy. Princeton: Princeton University Press.

Vergne, C. (2009). Democracy, elections and allocation of public expenditures in developing countries. European Journal of Political Economy, 25(1), 63-77. https://doi.org/10.1016/j.ejpoleco.2008.09.003

Vicente, C., Ríos, A., \& Guillamón, M. D. (2013). Voting behavior and budget stability. Revista de Contabilidad Spanish Accounting Review, 16(1), 46-52. https://doi.org/10.1016/S1138-4891(13)70005-0

\section{Appendices}

\section{Appendice 1. Graphical representation of the cycles}

\section{Capital Expenditure}

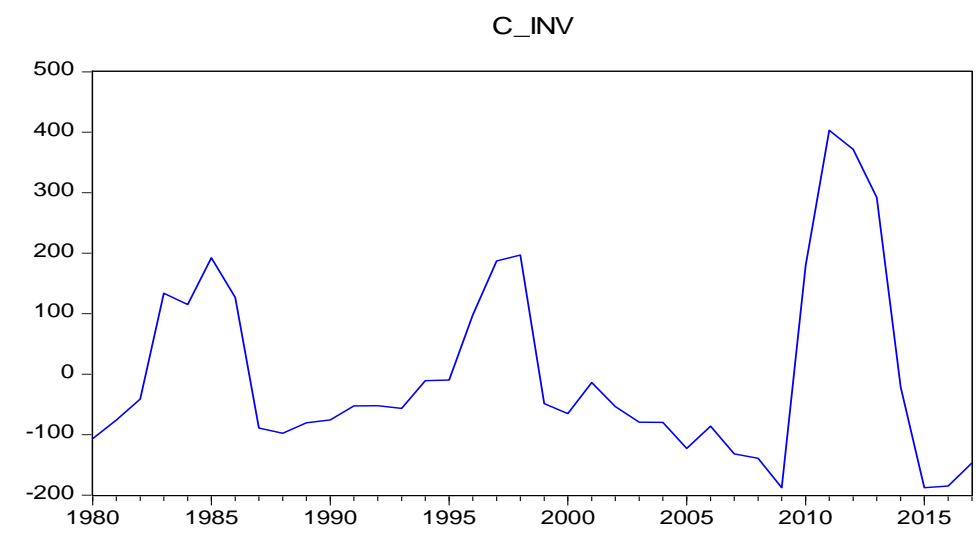




\section{Current expenditure}

C_DC

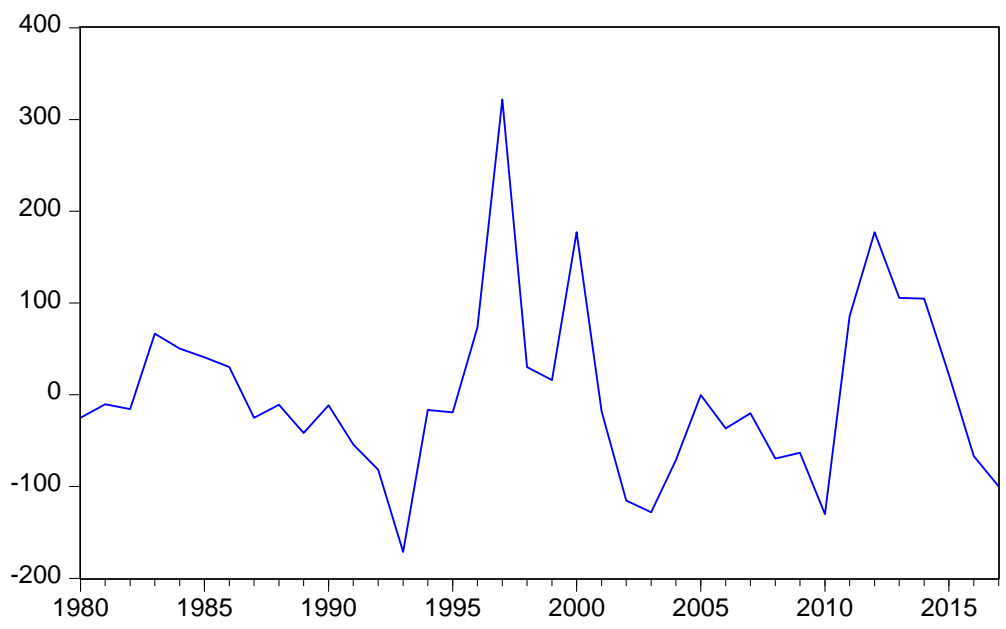

\section{Total expenditure}

C_DT

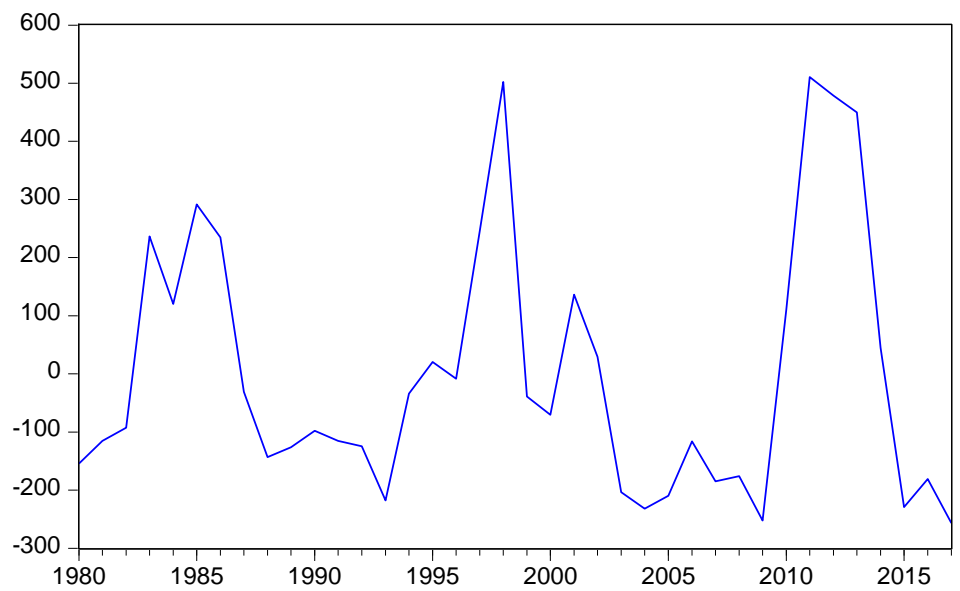

\section{Budget deficit}

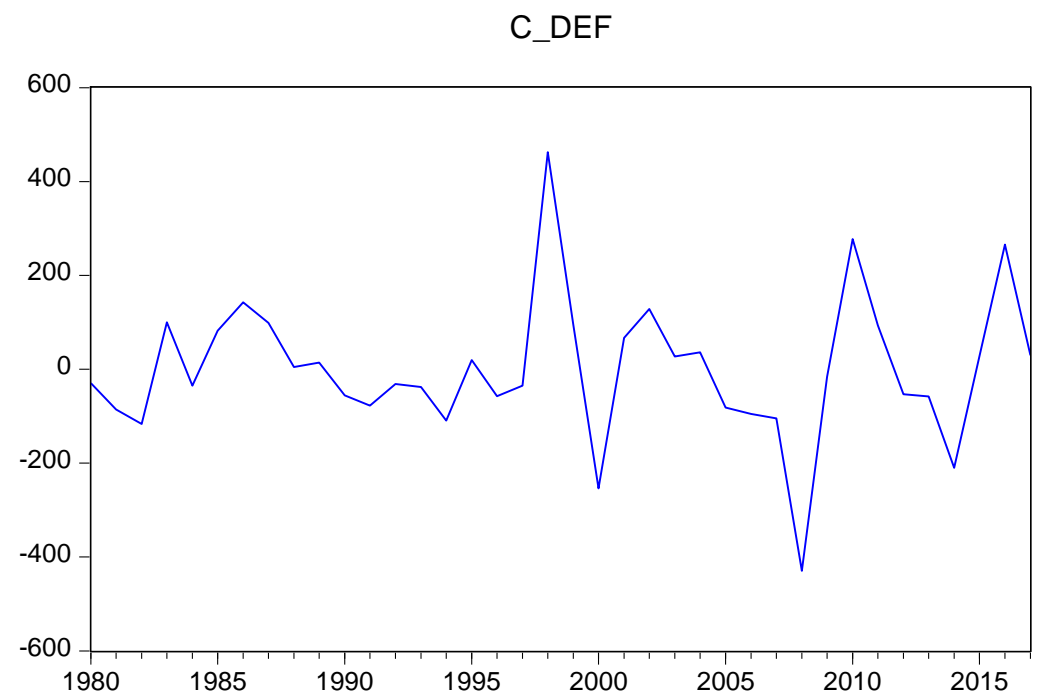




\section{Appendice 2. MVCE}

\section{Capital Expenditure}

\section{$\checkmark$ Estimation}

Vector Error Correction Estimates

Date: 03/06/19 Time: 08:14

Sample (adjusted): 19832017

Included observations: 35 after adjustments

Standard errors in ( ) \& t-statistics in [ ]

\begin{tabular}{|c|c|c|c|c|c|}
\hline Cointegrating Eq: & CointEq1 & & & & \\
\hline C_INV(-1) & 1.000000 & & & & \\
\hline $\mathrm{ELE}(-1)$ & $\begin{array}{l}214.4631 \\
(99.0633) \\
{[2.16491]}\end{array}$ & & & & \\
\hline $\operatorname{INF}(-1)$ & $\begin{array}{r}-15.60874 \\
(4.25557) \\
{[-3.66784]}\end{array}$ & & & & \\
\hline $\operatorname{TIR}(-1)$ & $\begin{array}{r}-0.287401 \\
(2.67246) \\
{[-0.10754]}\end{array}$ & & & & \\
\hline $\mathrm{PIB}(-1)$ & $\begin{array}{r}-0.014623 \\
(0.01070) \\
{[-1.36658]}\end{array}$ & & & & \\
\hline $\mathrm{C}$ & 34.23243 & & & & \\
\hline Error Correction: & $\mathrm{D}\left(\mathrm{C} \_\mathrm{INV}\right)$ & $\mathrm{D}(\mathrm{ELE})$ & $\mathrm{D}(\mathrm{INF})$ & $\mathrm{D}(\mathrm{TIR})$ & $\mathrm{D}(\mathrm{PIB})$ \\
\hline CointEq1 & $\begin{array}{r}-0.669153 \\
(0.10127) \\
{[-6.60757]}\end{array}$ & $\begin{array}{r}-0.001403 \\
(0.00091) \\
{[-1.54750]}\end{array}$ & $\begin{array}{c}0.021487 \\
(0.01371) \\
{[1.56706]}\end{array}$ & $\begin{array}{r}-0.039544 \\
(0.02402) \\
{[-1.64603]}\end{array}$ & $\begin{array}{r}-0.457786 \\
(0.81524) \\
{[-0.56154]}\end{array}$ \\
\hline D(C_INV(-1)) & $\begin{array}{l}0.771222 \\
(0.13350) \\
{[5.77684]}\end{array}$ & $\begin{array}{c}0.000626 \\
(0.00120) \\
{[0.52356]}\end{array}$ & $\begin{array}{r}-0.013039 \\
(0.01808) \\
{[-0.72138]}\end{array}$ & $\begin{array}{c}0.063338 \\
(0.03167) \\
{[1.99995]}\end{array}$ & $\begin{array}{c}1.631326 \\
(1.07471) \\
{[1.51793]}\end{array}$ \\
\hline $\mathrm{D}\left(\mathrm{C}_{-} \mathrm{INV}(-2)\right)$ & $\begin{array}{l}0.658122 \\
(0.18714) \\
{[3.51665]}\end{array}$ & $\begin{array}{r}-0.000644 \\
(0.00168) \\
{[-0.38446]}\end{array}$ & $\begin{array}{r}-0.012654 \\
(0.02534) \\
{[-0.49942]}\end{array}$ & $\begin{array}{l}0.006980 \\
(0.04439) \\
{[0.15722]}\end{array}$ & $\begin{array}{l}1.887238 \\
(1.50653) \\
{[1.25271]}\end{array}$ \\
\hline $\mathrm{D}(\mathrm{ELE}(-1))$ & $\begin{array}{l}87.17635 \\
(23.1493) \\
{[3.76584]}\end{array}$ & $\begin{array}{r}-0.674005 \\
(0.20727) \\
{[-3.25189]}\end{array}$ & $\begin{array}{l}0.821315 \\
(3.13429) \\
{[0.26204]}\end{array}$ & $\begin{array}{r}-5.644669 \\
(5.49154) \\
{[-1.02788]}\end{array}$ & $\begin{array}{l}178.2411 \\
(186.353) \\
{[0.95647]}\end{array}$ \\
\hline $\mathrm{D}(\mathrm{ELE}(-2))$ & $\begin{array}{l}60.02111 \\
(20.4379) \\
{[2.93675]}\end{array}$ & $\begin{array}{r}-0.391917 \\
(0.18299) \\
{[-2.14174]}\end{array}$ & $\begin{array}{c}2.034124 \\
(2.76719) \\
{[0.73509]}\end{array}$ & $\begin{array}{r}-4.054602 \\
(4.84835) \\
{[-0.83628]}\end{array}$ & $\begin{array}{l}216.3332 \\
(164.527) \\
{[1.31488]}\end{array}$ \\
\hline $\mathrm{D}(\operatorname{INF}(-1))$ & -10.21162 & -0.026972 & -0.036872 & -0.380719 & -16.35108 \\
\hline
\end{tabular}




\begin{tabular}{|c|c|c|c|c|c|}
\hline & $\begin{array}{r}(1.65327) \\
{[-6.17664]}\end{array}$ & $\begin{array}{r}(0.01480) \\
{[-1.82216]}\end{array}$ & $\begin{array}{c}(0.22384) \\
{[-0.16472]}\end{array}$ & $\begin{array}{r}(0.39219) \\
{[-0.97074]}\end{array}$ & $\begin{array}{r}(13.3089) \\
{[-1.22858]}\end{array}$ \\
\hline $\mathrm{D}(\mathrm{INF}(-2))$ & $\begin{array}{r}-7.614201 \\
(1.86016) \\
{[-4.09330]}\end{array}$ & $\begin{array}{r}-0.009990 \\
(0.01665) \\
{[-0.59982]}\end{array}$ & $\begin{array}{r}-0.306269 \\
(0.25186) \\
{[-1.21605]}\end{array}$ & $\begin{array}{r}-0.683808 \\
(0.44127) \\
{[-1.54962]}\end{array}$ & $\begin{array}{c}0.098773 \\
(14.9745) \\
{[0.00660]}\end{array}$ \\
\hline $\mathrm{D}(\mathrm{TIR}(-1))$ & $\begin{array}{r}-4.630301 \\
(0.98817) \\
{[-4.68573]}\end{array}$ & $\begin{array}{r}-0.003793 \\
(0.00885) \\
{[-0.42874]}\end{array}$ & $\begin{array}{r}-0.009856 \\
(0.13379) \\
{[-0.07367]}\end{array}$ & $\begin{array}{r}-0.530177 \\
(0.23442) \\
{[-2.26168]}\end{array}$ & $\begin{array}{r}-15.75684 \\
(7.95485) \\
{[-1.98078]}\end{array}$ \\
\hline $\mathrm{D}(\mathrm{TIR}(-2))$ & $\begin{array}{r}-5.050776 \\
(1.10992) \\
{[-4.55057]}\end{array}$ & $\begin{array}{c}0.001502 \\
(0.00994) \\
{[0.15117]}\end{array}$ & $\begin{array}{r}-0.144120 \\
(0.15028) \\
{[-0.95902]}\end{array}$ & $\begin{array}{c}-0.338204 \\
(0.26330) \\
{[-1.28448]}\end{array}$ & $\begin{array}{r}-12.43307 \\
(8.93496) \\
{[-1.39151]}\end{array}$ \\
\hline $\mathrm{D}(\mathrm{PIB}(-1))$ & $\begin{array}{r}-0.104415 \\
(0.03009) \\
{[-3.46990]}\end{array}$ & $\begin{array}{c}0.000140 \\
(0.00027) \\
{[0.51822]}\end{array}$ & $\begin{array}{r}-0.000608 \\
(0.00407) \\
{[-0.14915]}\end{array}$ & $\begin{array}{r}-0.002825 \\
(0.00714) \\
{[-0.39578]}\end{array}$ & $\begin{array}{r}-0.417710 \\
(0.24224) \\
{[-1.72437]}\end{array}$ \\
\hline $\mathrm{D}(\mathrm{PIB}(-2))$ & $\begin{array}{r}-0.032591 \\
(0.03047) \\
{[-1.06952]}\end{array}$ & $\begin{array}{r}-4.05 E-05 \\
(0.00027) \\
{[-0.14851]}\end{array}$ & $\begin{array}{r}-0.000714 \\
(0.00413) \\
{[-0.17296]}\end{array}$ & $\begin{array}{l}0.007727 \\
(0.00723) \\
{[1.06896]}\end{array}$ & $\begin{array}{r}-0.384945 \\
(0.24530) \\
{[-1.56925]}\end{array}$ \\
\hline $\mathrm{C}$ & $\begin{array}{l}20.48844 \\
(14.7319) \\
{[1.39075]}\end{array}$ & $\begin{array}{r}-0.011326 \\
(0.13190) \\
{[-0.08587]}\end{array}$ & $\begin{array}{r}-0.344791 \\
(1.99462) \\
{[-0.17286]}\end{array}$ & $\begin{array}{r}-1.775397 \\
(3.49475) \\
{[-0.50802]}\end{array}$ & $\begin{array}{l}375.2670 \\
(118.593) \\
{[3.16433]}\end{array}$ \\
\hline $\begin{array}{l}\text { R-squared } \\
\text { Adj. R-squared } \\
\text { Sum sq. resids } \\
\text { S.E. equation } \\
\text { F-statistic } \\
\text { Log likelihood } \\
\text { Akaike AIC } \\
\text { Schwarz SC } \\
\text { Mean dependent } \\
\text { S.D. dependent }\end{array}$ & $\begin{array}{r}0.805687 \\
0.712755 \\
97786.97 \\
65.20435 \\
8.669605 \\
-188.5288 \\
11.45879 \\
11.99205 \\
-3.015828 \\
121.6606\end{array}$ & $\begin{array}{r}0.608049 \\
0.420595 \\
7.839014 \\
0.583804 \\
3.243713 \\
-23.47874 \\
2.027356 \\
2.560619 \\
0.000000 \\
0.766965\end{array}$ & $\begin{array}{r}0.426301 \\
0.151923 \\
1792.605 \\
8.828327 \\
1.553698 \\
-118.5442 \\
7.459669 \\
7.992931 \\
-0.426451 \\
9.586513\end{array}$ & $\begin{array}{r}0.473194 \\
0.221243 \\
5502.939 \\
15.46797 \\
1.878121 \\
-138.1724 \\
8.581281 \\
9.114543 \\
-0.474857 \\
17.52801\end{array}$ & $\begin{array}{l}0.326472 \\
0.004350 \\
6336965 . \\
524.9002 \\
1.013504 \\
-261.5277 \\
15.63015 \\
16.16342 \\
211.2543 \\
526.0456\end{array}$ \\
\hline $\begin{array}{l}\text { Determinant resid ce } \\
\text { Determinant resid ce } \\
\text { Log likelihood } \\
\text { Akaike information } \\
\text { Schwarz criterion }\end{array}$ & (dof adj.) & $\begin{array}{r}3.05 \mathrm{E}+12 \\
3.74 \mathrm{E}+11 \\
-714.6278 \\
44.55016 \\
47.43866\end{array}$ & & & \\
\hline
\end{tabular}

\section{Autocorrélation test}

\begin{tabular}{ccc}
\hline \hline Lags & LM-Stat & Prob \\
\hline \hline 1 & 19.86393 & 0.7539 \\
2 & 38.37646 & 0.0425 \\
\hline \hline
\end{tabular}




\section{$\checkmark$ Heteroscédasticity test}

Joint test:

\begin{tabular}{ccc}
\hline \hline Chi-sq & df & Prob. \\
\hline \hline 313.4307 & 330 & 0.7357 \\
\hline \hline
\end{tabular}

\section{$\checkmark \quad$ Stability test}

Inverse Roots of AR Characteristic Polynomial

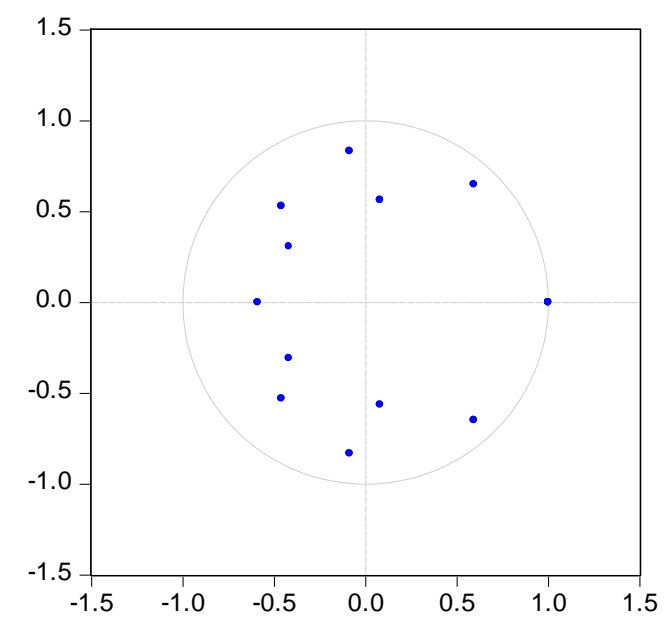

\section{Current Expenditure}

\section{$\checkmark$ Estimation}

Vector Error Correction Estimates

Date: 03/06/19 Time: 08:20

Sample (adjusted): 19832017

Included observations: 35 after adjustments

Standard errors in ( ) \& t-statistics in [ ]

\begin{tabular}{cc}
\hline \hline Cointegrating Eq: & CointEq1 \\
\hline \hline C_DC(-1) & 1.000000 \\
& $\mathbf{1 1 9 3 . 0 2 1}$ \\
ELE(-1) & $\mathbf{2 6 7 . 8 6 6 )}$ \\
& $\mathbf{4 . 4 5 3 7 9 ]}$ \\
& -48.52114 \\
INF(-1) & $(13.4085)$ \\
& {$[-3.61869]$} \\
& 15.80953 \\
TIR(-1) & $(7.76856)$ \\
& {$[2.03507]$} \\
& 0.217975 \\
PIB(-1) & $(0.07222)$
\end{tabular}


[3.01800]

@TREND(80) $\quad-47.97566$

(15.8461)

[-3.02760]

$\mathrm{C}$

$-233.4567$

\begin{tabular}{|c|c|c|c|c|c|}
\hline Error Correction: & $\mathrm{D}\left(\mathrm{C} \_\mathrm{DC}\right)$ & $\mathrm{D}(\mathrm{ELE})$ & $\mathrm{D}(\mathrm{INF})$ & $\mathrm{D}$ (TIR) & $\mathrm{D}(\mathrm{PIB})$ \\
\hline CointEq1 & $\begin{array}{c}-0.067519 \\
(0.05308) \\
{[-1.27204]}\end{array}$ & $\begin{array}{r}-0.000725 \\
(0.00030) \\
{[-2.43992]}\end{array}$ & $\begin{array}{c}0.006023 \\
(0.00443) \\
{[1.35930]}\end{array}$ & $\begin{array}{r}-0.017267 \\
(0.00820) \\
{[-2.10620]}\end{array}$ & $\begin{array}{c}0.099035 \\
(0.32926) \\
{[0.30078]}\end{array}$ \\
\hline D(C_DC(-1)) & $\begin{array}{r}-0.388535 \\
(0.23735) \\
{[-1.63696]}\end{array}$ & $\begin{array}{c}0.000708 \\
(0.00133) \\
{[0.53305]}\end{array}$ & $\begin{array}{r}-0.039504 \\
(0.01981) \\
{[-1.99369]}\end{array}$ & $\begin{array}{c}0.053908 \\
(0.03666) \\
{[1.47050]}\end{array}$ & $\begin{array}{r}-0.271575 \\
(1.47233) \\
{[-0.18445]}\end{array}$ \\
\hline D(C_DC(-2)) & $\begin{array}{c}-0.180711 \\
(0.21342) \\
{[-0.84672]}\end{array}$ & $\begin{array}{c}0.002409 \\
(0.00119) \\
{[2.01780]}\end{array}$ & $\begin{array}{r}-0.025947 \\
(0.01782) \\
{[-1.45633]}\end{array}$ & $\begin{array}{c}0.019302 \\
(0.03296) \\
{[0.58555]}\end{array}$ & $\begin{array}{r}-0.267554 \\
(1.32390) \\
{[-0.20209]}\end{array}$ \\
\hline $\mathrm{D}(\operatorname{ELE}(-1))$ & $\begin{array}{c}84.15146 \\
(46.4114) \\
{[1.81316]}\end{array}$ & $\begin{array}{r}-0.241689 \\
(0.25966) \\
{[-0.93080]}\end{array}$ & $\begin{array}{r}-2.613469 \\
(3.87446) \\
{[-0.67454]}\end{array}$ & $\begin{array}{c}6.230083 \\
(7.16831) \\
{[0.86911]}\end{array}$ & $\begin{array}{c}78.54270 \\
(287.897) \\
{[0.27282]}\end{array}$ \\
\hline $\mathrm{D}(\operatorname{ELE}(-2))$ & $\begin{array}{c}41.10828 \\
(33.0885) \\
{[1.24237]}\end{array}$ & $\begin{array}{c}-0.221220 \\
(0.18512) \\
{[-1.19501]}\end{array}$ & $\begin{array}{c}0.572383 \\
(2.76226) \\
{[0.20722]}\end{array}$ & $\begin{array}{c}1.924704 \\
(5.11057) \\
{[0.37661]}\end{array}$ & $\begin{array}{c}240.1634 \\
(205.253) \\
{[1.17009]}\end{array}$ \\
\hline $\mathrm{D}(\mathrm{INF}(-1))$ & $\begin{array}{r}-4.326771 \\
(2.44051) \\
{[-1.77290]}\end{array}$ & $\begin{array}{r}-0.035598 \\
(0.01365) \\
{[-2.60722]}\end{array}$ & $\begin{array}{r}-0.087262 \\
(0.20374) \\
{[-0.42831]}\end{array}$ & $\begin{array}{r}-0.387981 \\
(0.37694) \\
{[-1.02929]}\end{array}$ & $\begin{array}{r}-5.238180 \\
(15.1388) \\
{[-0.34601]}\end{array}$ \\
\hline $\mathrm{D}(\mathrm{INF}(-2))$ & $\begin{array}{c}0.007536 \\
(2.78578) \\
{[0.00271]}\end{array}$ & $\begin{array}{r}-0.018964 \\
(0.01559) \\
{[-1.21680]}\end{array}$ & $\begin{array}{r}-0.451897 \\
(0.23256) \\
{[-1.94315]}\end{array}$ & $\begin{array}{c}-0.713013 \\
(0.43027) \\
{[-1.65714]}\end{array}$ & $\begin{array}{c}9.487464 \\
(17.2806) \\
{[0.54902]}\end{array}$ \\
\hline $\mathrm{D}(\mathrm{TIR}(-1))$ & $\begin{array}{r}-0.232315 \\
(1.43691) \\
{[-0.16168]}\end{array}$ & $\begin{array}{r}-0.006125 \\
(0.00804) \\
{[-0.76193]}\end{array}$ & $\begin{array}{r}-0.075556 \\
(0.11995) \\
{[-0.62987]}\end{array}$ & $\begin{array}{r}-0.168728 \\
(0.22193) \\
{[-0.76027]}\end{array}$ & $\begin{array}{r}-7.127724 \\
(8.91334) \\
{[-0.79967]}\end{array}$ \\
\hline $\mathrm{D}(\mathrm{TIR}(-2))$ & $\begin{array}{c}1.665814 \\
(1.24701) \\
{[1.33584]}\end{array}$ & $\begin{array}{c}-0.001682 \\
(0.00698) \\
{[-0.24110]}\end{array}$ & $\begin{array}{r}-0.262111 \\
(0.10410) \\
{[-2.51783]}\end{array}$ & $\begin{array}{c}-0.212049 \\
(0.19260) \\
{[-1.10097]}\end{array}$ & $\begin{array}{r}-3.958158 \\
(7.73541) \\
{[-0.51169]}\end{array}$ \\
\hline $\mathrm{D}(\mathrm{PIB}(-1))$ & $\begin{array}{c}0.115066 \\
(0.03867) \\
{[2.97531]}\end{array}$ & $\begin{array}{c}8.55 \mathrm{E}-05 \\
(0.00022) \\
{[0.39506]}\end{array}$ & $\begin{array}{c}0.000283 \\
(0.00323) \\
{[0.08772]}\end{array}$ & $\begin{array}{c}0.002063 \\
(0.00597) \\
{[0.34542]}\end{array}$ & $\begin{array}{r}-0.072626 \\
(0.23990) \\
{[-0.30274]}\end{array}$ \\
\hline $\mathrm{D}(\mathrm{PIB}(-2))$ & $\begin{array}{c}0.011952 \\
(0.04501) \\
{[0.26553]}\end{array}$ & $\begin{array}{r}-0.000257 \\
(0.00025) \\
{[-1.01921]}\end{array}$ & $\begin{array}{c}0.002475 \\
(0.00376) \\
{[0.65859]}\end{array}$ & $\begin{array}{c}0.003935 \\
(0.00695) \\
{[0.56605]}\end{array}$ & $\begin{array}{r}-0.183782 \\
(0.27921) \\
{[-0.65822]}\end{array}$ \\
\hline $\mathrm{C}$ & -32.87787 & 0.026305 & -1.174471 & -2.275184 & 262.4218 \\
\hline
\end{tabular}




\begin{tabular}{lrrrrr} 
& $(22.3928)$ & $(0.12528)$ & $(1.86937)$ & $(3.45859)$ & $(138.906)$ \\
& {$[-1.46824]$} & {$[0.20997]$} & {$[-0.62827]$} & {$[-0.65784]$} & {$[1.88921]$} \\
\hline \hline R-squared & 0.456553 & 0.686468 & 0.553175 & 0.542487 & 0.180663 \\
Adj. R-squared & 0.196644 & 0.536518 & 0.339477 & 0.323676 & -0.211193 \\
Sum sq. resids & 200338.4 & 6.270646 & 1396.167 & 4779.116 & 7708824. \\
S.E. equation & 93.32933 & 0.522146 & 7.791207 & 14.41484 & 578.9355 \\
F-statistic & 1.756586 & 4.577971 & 2.588576 & 2.479252 & 0.461044 \\
Log likelihood & -201.0801 & -19.57215 & -114.1703 & -135.7044 & -264.9571 \\
Akaike AIC & 12.17601 & 1.804123 & 7.209729 & 8.440254 & 15.82612 \\
Schwarz SC & 12.70927 & 2.337385 & 7.742991 & 8.973516 & 16.35938 \\
Mean dependent & -2.408855 & 0.000000 & -0.426451 & -0.474857 & 211.2543 \\
S.D. dependent & 104.1272 & 0.766965 & 9.586513 & 17.52801 & 526.0456 \\
\hline \hline Determinant resid covariance (dof adj.) & $1.92 \mathrm{E}+12$ & & & \\
Determinant resid covariance & $2.36 \mathrm{E}+11$ & & & \\
Log likelihood & -706.5598 & & & \\
Akaike information criterion & 44.14627 & & & \\
Schwarz criterion & 47.07922 & & & \\
\hline \hline
\end{tabular}

\section{Autocorrélation test}

\begin{tabular}{ccc}
\hline \hline Lags & LM-Stat & Prob \\
\hline \hline 1 & 19.86393 & 0.7539 \\
2 & 38.37646 & 0.0425 \\
\hline \hline
\end{tabular}

\section{Heteroscédasticity Test}

Joint test:

\begin{tabular}{ccc}
\hline \hline Chi-sq & df & Prob. \\
\hline \hline 313.4307 & 330 & 0.7357 \\
\hline \hline
\end{tabular}

\section{$\checkmark \quad$ Stability test}

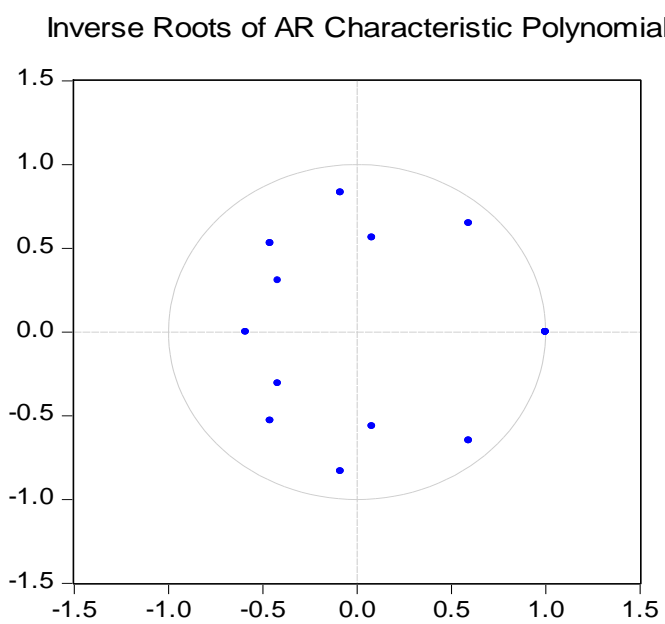




\section{Total Expenditure}

\section{$\checkmark$ Estimation}

Vector Error Correction Estimates

Date: 03/06/19 Time: 18:33

Sample (adjusted): 19832017

Included observations: 35 after adjustments

Standard errors in ( ) \& t-statistics in [ ]

\begin{tabular}{|c|c|c|c|c|c|}
\hline Cointegrating Eq: & CointEq1 & & & & \\
\hline C_DT(-1) & 1.000000 & & & & \\
\hline ELE(-1) & $\begin{array}{c}1082.562 \\
(215.278) \\
{[5.02866]}\end{array}$ & & & & \\
\hline $\operatorname{INF}(-1)$ & $\begin{array}{r}-36.40787 \\
(6.14599) \\
{[-5.92384]}\end{array}$ & & & & \\
\hline $\operatorname{TIR}(-1)$ & $\begin{array}{r}-7.274879 \\
(3.34409) \\
{[-2.17544]}\end{array}$ & & & & \\
\hline $\mathrm{PIB}(-1)$ & $\begin{array}{r}-0.040149 \\
(0.01327) \\
{[-3.02472]}\end{array}$ & & & & \\
\hline Error Correction: & $\mathrm{D}\left(\mathrm{C} \_\mathrm{DT}\right)$ & $\mathrm{D}(\mathrm{ELE})$ & $\mathrm{D}(\mathrm{INF})$ & $\mathrm{D}(\mathrm{TIR})$ & $\mathrm{D}(\mathrm{PIB})$ \\
\hline CointEq1 & $\begin{array}{r}\mathbf{- 0 . 5 1 1 2 3 0} \\
(0.09913) \\
{[-5.15742]}\end{array}$ & $\begin{array}{c}-0.001031 \\
(0.00033) \\
{[-3.10225]}\end{array}$ & $\begin{array}{l}0.010321 \\
(0.00619) \\
{[1.66663]}\end{array}$ & $\begin{array}{r}-0.019793 \\
(0.01072) \\
{[-1.84587]}\end{array}$ & $\begin{array}{r}-0.044008 \\
(0.46912) \\
{[-0.09381]}\end{array}$ \\
\hline D(C_DT(-1)) & $\begin{array}{c}0.669991 \\
(0.17685) \\
{[3.78839]}\end{array}$ & $\begin{array}{c}0.001089 \\
(0.00059) \\
{[1.83713]}\end{array}$ & $\begin{array}{r}-0.021800 \\
(0.01105) \\
{[-1.97320]}\end{array}$ & $\begin{array}{c}0.058609 \\
(0.01913) \\
{[3.06361]}\end{array}$ & $\begin{array}{c}0.166435 \\
(0.83698) \\
{[0.19885]}\end{array}$ \\
\hline D(C_DT(-2)) & $\begin{array}{c}0.581181 \\
(0.21293) \\
{[2.72950]}\end{array}$ & $\begin{array}{c}-0.000932 \\
(0.00071) \\
{[-1.30582]}\end{array}$ & $\begin{array}{r}-0.002241 \\
(0.01330) \\
{[-0.16847]}\end{array}$ & $\begin{array}{c}0.002050 \\
(0.02303) \\
{[0.08901]}\end{array}$ & $\begin{array}{c}0.382609 \\
(1.00769) \\
{[0.37969]}\end{array}$ \\
\hline D(ELE(-1)) & $\begin{array}{c}323.2474 \\
(77.8114) \\
{[4.15424]}\end{array}$ & $\begin{array}{r}-0.159776 \\
(0.26085) \\
{[-0.61251]}\end{array}$ & $\begin{array}{r}-2.884349 \\
(4.86097) \\
{[-0.59337]}\end{array}$ & $\begin{array}{c}1.616656 \\
(8.41708) \\
{[0.19207]}\end{array}$ & $\begin{array}{c}209.2405 \\
(368.249) \\
{[0.56820]}\end{array}$ \\
\hline D(ELE(-2)) & $\begin{array}{c}200.6015 \\
(47.5126) \\
{[4.22207]}\end{array}$ & $\begin{array}{c}-0.092605 \\
(0.15928) \\
{[-0.58140]}\end{array}$ & $\begin{array}{c}0.005724 \\
(2.96817) \\
{[0.00193]}\end{array}$ & $\begin{array}{c}0.353738 \\
(5.13957) \\
{[0.06883]}\end{array}$ & $\begin{array}{c}275.1741 \\
(224.857) \\
{[1.22377]}\end{array}$ \\
\hline $\mathrm{D}(\mathrm{INF}(-1))$ & $\begin{array}{r}-13.89520 \\
(3.54080) \\
{[-3.92432]}\end{array}$ & $\begin{array}{r}-0.042767 \\
(0.01187) \\
{[-3.60288]}\end{array}$ & $\begin{array}{c}0.088234 \\
(0.22120) \\
{[0.39889]}\end{array}$ & $\begin{array}{r}-0.689849 \\
(0.38302) \\
{[-1.80109]}\end{array}$ & $\begin{array}{r}-11.14961 \\
(16.7571) \\
{[-0.66537]}\end{array}$ \\
\hline
\end{tabular}




\begin{tabular}{|c|c|c|c|c|c|}
\hline $\mathrm{D}(\mathrm{INF}(-2))$ & $\begin{array}{c}-20.34824 \\
(4.06846) \\
{[-5.00146]}\end{array}$ & $\begin{array}{r}-0.011354 \\
(0.01364) \\
{[-0.83250]}\end{array}$ & $\begin{array}{r}-0.286489 \\
(0.25416) \\
{[-1.12719]}\end{array}$ & $\begin{array}{r}-0.828439 \\
(0.44010) \\
{[-1.88240]}\end{array}$ & $\begin{array}{c}3.020648 \\
(19.2543) \\
{[0.15688]}\end{array}$ \\
\hline $\mathrm{D}(\mathrm{TIR}(-1))$ & $\begin{array}{r}-8.795386 \\
(2.26693) \\
{[-3.87987]}\end{array}$ & $\begin{array}{r}-0.011448 \\
(0.00760) \\
{[-1.50635]}\end{array}$ & $\begin{array}{l}0.139822 \\
(0.14162) \\
{[0.98732]}\end{array}$ & $\begin{array}{r}-0.819405 \\
(0.24522) \\
{[-3.34150]}\end{array}$ & $\begin{array}{r}-9.198528 \\
(10.7284) \\
{[-0.85740]}\end{array}$ \\
\hline $\mathrm{D}(\mathrm{TIR}(-2))$ & $\begin{array}{r}-12.18544 \\
(2.50618) \\
{[-4.86217]}\end{array}$ & $\begin{array}{l}0.002111 \\
(0.00840) \\
{[0.25120]}\end{array}$ & $\begin{array}{r}-0.119345 \\
(0.15656) \\
{[-0.76228]}\end{array}$ & $\begin{array}{r}-0.470001 \\
(0.27110) \\
{[-1.73368]}\end{array}$ & $\begin{array}{r}-4.949342 \\
(11.8607) \\
{[-0.41729]}\end{array}$ \\
\hline $\mathrm{D}(\mathrm{PIB}(-1))$ & $\begin{array}{r}-0.058376 \\
(0.05242) \\
{[-1.11362]}\end{array}$ & $\begin{array}{c}5.63 \mathrm{E}-05 \\
(0.00018) \\
{[0.32019]}\end{array}$ & $\begin{array}{l}0.000999 \\
(0.00327) \\
{[0.30498]}\end{array}$ & $\begin{array}{r}-0.006382 \\
(0.00567) \\
{[-1.12550]}\end{array}$ & $\begin{array}{c}0.055493 \\
(0.24808) \\
{[0.22369]}\end{array}$ \\
\hline $\mathrm{D}(\mathrm{PIB}(-2))$ & $\begin{array}{r}-0.011757 \\
(0.04825) \\
{[-0.24366]}\end{array}$ & $\begin{array}{c}7.72 \mathrm{E}-05 \\
(0.00016) \\
{[0.47697]}\end{array}$ & $\begin{array}{r}-0.001951 \\
(0.00301) \\
{[-0.64736]}\end{array}$ & $\begin{array}{c}0.006054 \\
(0.00522) \\
{[1.15980]}\end{array}$ & $\begin{array}{r}-0.059821 \\
(0.22836) \\
{[-0.26196]}\end{array}$ \\
\hline $\begin{array}{l}\text { R-squared } \\
\text { Adj. R-squared } \\
\text { Sum sq. resids } \\
\text { S.E. equation } \\
\text { F-statistic } \\
\text { Log likelihood } \\
\text { Akaike AIC } \\
\text { Schwarz SC } \\
\text { Mean dependent } \\
\text { S.D. dependent }\end{array}$ & $\begin{array}{r}0.695350 \\
0.568413 \\
419975.4 \\
132.2837 \\
5.477899 \\
-214.0334 \\
12.85905 \\
13.34788 \\
-4.691727 \\
201.3595\end{array}$ & $\begin{array}{r}0.764005 \\
0.665674 \\
4.719894 \\
0.443466 \\
7.769720 \\
-14.60052 \\
1.462887 \\
1.951710 \\
0.000000 \\
0.766965\end{array}$ & $\begin{array}{r}0.475455 \\
0.256894 \\
1639.016 \\
8.263917 \\
2.175392 \\
-116.9767 \\
7.312952 \\
7.801775 \\
-0.426451 \\
9.586513\end{array}$ & $\begin{array}{r}0.529547 \\
0.333524 \\
4914.288 \\
14.30951 \\
2.701462 \\
-136.1925 \\
8.411003 \\
8.899826 \\
-0.474857 \\
17.52801\end{array}$ & $\begin{array}{r}0.000240 \\
-0.416326 \\
9406353 . \\
626.0442 \\
0.000577 \\
-268.4399 \\
15.96800 \\
16.45682 \\
211.2543 \\
526.0456\end{array}$ \\
\hline $\begin{array}{l}\text { Determinant resid c } \\
\text { Determinant resid c } \\
\text { Log likelihood } \\
\text { Akaike information } \\
\text { Schwarz criterion }\end{array}$ & (dof adj.) & $\begin{array}{r}6.83 \mathrm{E}+12 \\
1.04 \mathrm{E}+12 \\
-732.4657 \\
45.28376 \\
47.95007\end{array}$ & & & \\
\hline
\end{tabular}

\section{$\checkmark$ Autocorrélation test}

\begin{tabular}{ccc}
\hline \hline Lags & LM-Stat & Prob \\
\hline \hline 1 & 20.77828 & 0.7049 \\
2 & 25.48596 & 0.4354 \\
\hline \hline
\end{tabular}

\section{Heteroscédasticity test}

\begin{tabular}{ccc}
\hline \hline Chi-sq & df & Prob. \\
\hline \hline 325.7272 & 330 & 0.5561 \\
\hline \hline
\end{tabular}




\section{Stability test}

Inverse Roots of AR Characteristic Polynomial

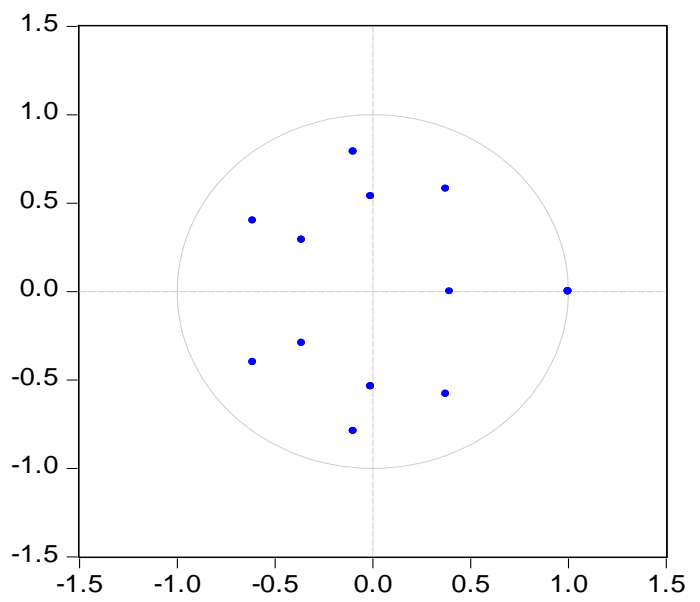

\section{Budget deficit}

\section{$\checkmark$ Estimation}

Vector Error Correction Estimates

Date: 03/06/19 Time: 18:58

Sample (adjusted): 19832017

Included observations: 35 after adjustments

Standard errors in ( ) \& t-statistics in [ ]

\begin{tabular}{|c|c|c|c|c|c|}
\hline Cointegrating Eq: & CointEq1 & & & & \\
\hline C_DEF(-1) & 1.000000 & & & & \\
\hline ELE(-1) & $\begin{array}{l}612.1722 \\
(103.794) \\
{[5.89793]}\end{array}$ & & & & \\
\hline $\operatorname{INF}(-1)$ & $\begin{array}{r}-6.657411 \\
(2.83085) \\
{[-2.35173]}\end{array}$ & & & & \\
\hline $\operatorname{TIR}(-1)$ & $\begin{array}{r}-9.704985 \\
(1.50471) \\
{[-6.44975]}\end{array}$ & & & & \\
\hline $\operatorname{PIB}(-1)$ & $\begin{array}{r}-0.021018 \\
(0.00493) \\
{[-4.26362]}\end{array}$ & & & & \\
\hline Error Correction: & $\mathrm{D}\left(\mathrm{C} \_\mathrm{DEF}\right)$ & $\mathrm{D}(\mathrm{ELE})$ & $\mathrm{D}(\mathrm{INF})$ & $\mathrm{D}(\mathrm{TIR})$ & $\mathrm{D}(\mathrm{PIB})$ \\
\hline CointEq1 & $\begin{array}{c}-0.926619 \\
(0.21956) \\
{[-4.22039]}\end{array}$ & $\begin{array}{r}-0.002537 \\
(0.00064) \\
{[-3.93503]}\end{array}$ & $\begin{array}{c}-0.007088 \\
(0.01336) \\
{[-0.53065]}\end{array}$ & $\begin{array}{l}0.015722 \\
(0.02523) \\
{[0.62318]}\end{array}$ & $\begin{array}{r}-0.162184 \\
(0.80198) \\
{[-0.20223]}\end{array}$ \\
\hline $\mathrm{D}\left(\mathrm{C} \_\mathrm{DEF}(-1)\right)$ & $\begin{array}{l}0.504538 \\
(0.26361)\end{array}$ & $\begin{array}{l}0.002437 \\
(0.00077)\end{array}$ & $\begin{array}{r}-0.001267 \\
(0.01604)\end{array}$ & $\begin{array}{r}-0.011821 \\
(0.03029)\end{array}$ & $\begin{array}{l}2.244674 \\
(0.96291)\end{array}$ \\
\hline
\end{tabular}




\begin{tabular}{|c|c|c|c|c|c|}
\hline & [1.91392] & [3.14838] & {$[-0.07899]$} & {$[-0.39024]$} & [2.33113] \\
\hline $\mathrm{D}\left(\mathrm{C} \_\mathrm{DEF}(-2)\right)$ & $\begin{array}{l}0.278085 \\
(0.28556) \\
{[0.97384]}\end{array}$ & $\begin{array}{c}5.36 \mathrm{E}-05 \\
(0.00084) \\
{[0.06395]}\end{array}$ & $\begin{array}{c}0.021295 \\
(0.01737) \\
{[1.22576]}\end{array}$ & $\begin{array}{r}-0.044768 \\
(0.03281) \\
{[-1.36435]}\end{array}$ & $\begin{array}{l}0.869872 \\
(1.04306) \\
{[0.83397]}\end{array}$ \\
\hline D(ELE(-1)) & $\begin{array}{l}342.3042 \\
(96.5316) \\
{[3.54603]}\end{array}$ & $\begin{array}{l}0.190694 \\
(0.28346) \\
{[0.67274]}\end{array}$ & $\begin{array}{c}6.146658 \\
(5.87300) \\
{[1.04660]}\end{array}$ & $\begin{array}{r}-13.94547 \\
(11.0924) \\
{[-1.25721]}\end{array}$ & $\begin{array}{l}5.265942 \\
(352.603) \\
{[0.01493]}\end{array}$ \\
\hline D(ELE(-2)) & $\begin{array}{r}175.1240 \\
(59.3437) \\
{[2.95101]}\end{array}$ & $\begin{array}{l}0.060887 \\
(0.17426) \\
{[0.34941]}\end{array}$ & $\begin{array}{c}3.393304 \\
(3.61048) \\
{[0.93985]}\end{array}$ & $\begin{array}{r}-4.778817 \\
(6.81916) \\
{[-0.70079]}\end{array}$ & $\begin{array}{l}89.86704 \\
(216.766) \\
{[0.41458]}\end{array}$ \\
\hline $\mathrm{D}(\mathrm{INF}(-1))$ & $\begin{array}{r}-0.298853 \\
(3.18804) \\
{[-0.09374]}\end{array}$ & $\begin{array}{r}-0.029301 \\
(0.00936) \\
{[-3.12997]}\end{array}$ & $\begin{array}{r}-0.153177 \\
(0.19396) \\
{[-0.78973]}\end{array}$ & $\begin{array}{r}-0.036268 \\
(0.36634) \\
{[-0.09900]}\end{array}$ & $\begin{array}{r}-16.30996 \\
(11.6450) \\
{[-1.40059]}\end{array}$ \\
\hline $\mathrm{D}(\mathrm{INF}(-2))$ & $\begin{array}{r}-8.635528 \\
(3.70074) \\
{[-2.33346]}\end{array}$ & $\begin{array}{r}-0.007122 \\
(0.01087) \\
{[-0.65543]}\end{array}$ & $\begin{array}{r}-0.604266 \\
(0.22515) \\
{[-2.68379]}\end{array}$ & $\begin{array}{r}-0.110045 \\
(0.42525) \\
{[-0.25878]}\end{array}$ & $\begin{array}{r}-7.267810 \\
(13.5178) \\
{[-0.53765]}\end{array}$ \\
\hline $\mathrm{D}(\mathrm{TIR}(-1))$ & $\begin{array}{r}-6.311393 \\
(2.69191) \\
{[-2.34458]}\end{array}$ & $\begin{array}{r}-0.028505 \\
(0.00790) \\
{[-3.60608]}\end{array}$ & $\begin{array}{r}-0.012778 \\
(0.16378) \\
{[-0.07802]}\end{array}$ & $\begin{array}{r}-0.302814 \\
(0.30933) \\
{[-0.97895]}\end{array}$ & $\begin{array}{r}-21.56424 \\
(9.83281) \\
{[-2.19309]}\end{array}$ \\
\hline $\mathrm{D}(\operatorname{TIR}(-2))$ & $\begin{array}{r}-8.435166 \\
(2.85176) \\
{[-2.95789]}\end{array}$ & $\begin{array}{r}-0.010260 \\
(0.00837) \\
{[-1.22520]}\end{array}$ & $\begin{array}{r}-0.318910 \\
(0.17350) \\
{[-1.83809]}\end{array}$ & $\begin{array}{r}-0.019284 \\
(0.32769) \\
{[-0.05885]}\end{array}$ & $\begin{array}{r}-12.24013 \\
(10.4167) \\
{[-1.17505]}\end{array}$ \\
\hline $\mathrm{D}(\mathrm{PIB}(-1))$ & $\begin{array}{r}-0.027392 \\
(0.05814) \\
{[-0.47116]}\end{array}$ & $\begin{array}{c}0.000391 \\
(0.00017) \\
{[2.29040]}\end{array}$ & $\begin{array}{r}-0.004621 \\
(0.00354) \\
{[-1.30652]}\end{array}$ & $\begin{array}{l}0.006449 \\
(0.00668) \\
{[0.96538]}\end{array}$ & $\begin{array}{c}0.156429 \\
(0.21236) \\
{[0.73662]}\end{array}$ \\
\hline $\mathrm{D}(\mathrm{PIB}(-2))$ & $\begin{array}{l}0.141541 \\
(0.06352) \\
{[2.22815]}\end{array}$ & $\begin{array}{r}-0.000120 \\
(0.00019) \\
{[-0.64106]}\end{array}$ & $\begin{array}{c}0.001835 \\
(0.00386) \\
{[0.47484]}\end{array}$ & $\begin{array}{r}-0.002780 \\
(0.00730) \\
{[-0.38084]}\end{array}$ & $\begin{array}{l}0.221029 \\
(0.23204) \\
{[0.95257]}\end{array}$ \\
\hline quared & 0.636600 & 0.784738 & 0.408516 & 0.368853 & 0.291940 \\
\hline R-squared & 0.485183 & 0.695045 & 0.162065 & 0.105875 & -0.003084 \\
\hline sq. resids & 499300.3 & 4.305246 & 1848.174 & 6592.869 & 6661861. \\
\hline equation & 144.2365 & 0.423539 & 8.775378 & 16.57416 & 526.8563 \\
\hline atistic & 4.204290 & 8.749187 & 1.657594 & 1.402601 & 0.989545 \\
\hline tike AIC & 13.03206 & $\begin{array}{r}-12.99150 \\
1.370935\end{array}$ & $\begin{array}{r}-119.0 / 84 \\
7.433054\end{array}$ & $\begin{array}{r}-141.3348 \\
8.704844\end{array}$ & $\begin{array}{r}-202.4021 \\
15.62301\end{array}$ \\
\hline warz SC & 13.52089 & 1.859758 & 7.921878 & 9.193668 & 16.11183 \\
\hline an dependent & 4.170802 & 0.000000 & -0.426451 & -0.474857 & 211.2543 \\
\hline dependent & 201.0245 & 0.766965 & 9.586513 & 17.52801 & 526.0456 \\
\hline erminant resid co & (dof adj.) & $4.27 \mathrm{E}+12$ & & & \\
\hline erminant resid co & & $6.47 \mathrm{E}+11$ & & & \\
\hline likelihood & & -724.2383 & & & \\
\hline ike information c & & 44.81362 & & & \\
\hline warz criterion & & 47.47993 & & & \\
\hline
\end{tabular}


$\checkmark$ Autocorrelation test

\begin{tabular}{ccc}
\hline \hline Lags & LM-Stat & Prob \\
\hline \hline 1 & 30.65455 & 0.2007 \\
2 & 21.15633 & 0.6839 \\
\hline \hline
\end{tabular}

\section{Heteroscédasticity test}

\begin{tabular}{ccc}
\hline \hline Chi-sq & df & Prob. \\
\hline \hline 324.6858 & 330 & 0.5722 \\
\hline \hline
\end{tabular}

\section{$\checkmark \quad$ Stability test}

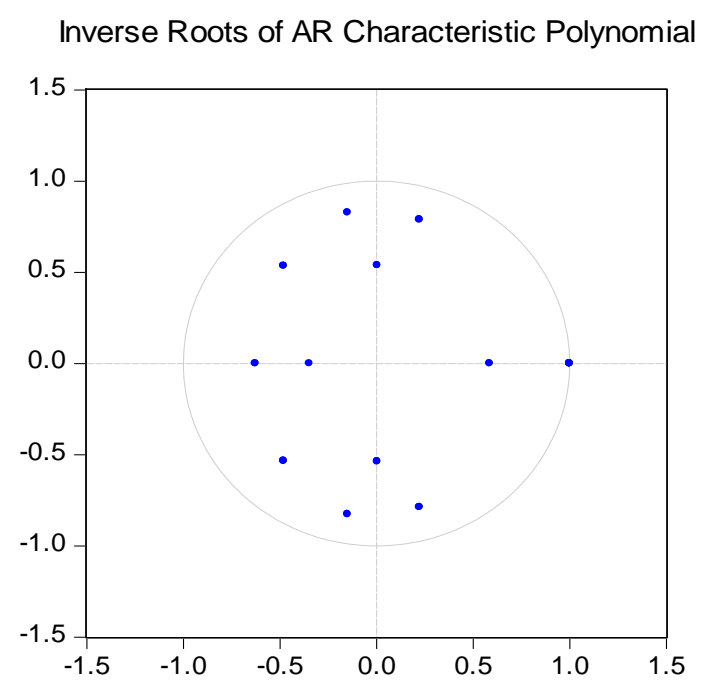

\section{Appendice 3: VAR Estimation}

VAR (1): current expenditure

\section{$\checkmark$ Estimation}

Bayesian VAR Estimates

Date: 04/21/19 Time: 03:35

Sample (adjusted): 19822017

Included observations: 36 after adjustments

Prior type: Litterman/Minnesota

Initial residual covariance: Univariate AR

Hyper-parameters: Mu: 0, L1: 0.1, L2: 0.99, L3: 1

Standard errors in ( ) \& t-statistics in [ ]

\begin{tabular}{cccccc}
\hline \hline & C_DC & ELE & INF & \multicolumn{1}{c}{ DPIB } & \multicolumn{1}{c}{ TIR } \\
\hline \hline C_DC(-1) & 0.125123 & $4.47 \mathrm{E}-05$ & -0.004573 & -0.622461 & 0.013677 \\
& $(0.08442)$ & $(0.00042)$ & $(0.00719)$ & $(0.49530)$ & $(0.01406)$ \\
& {$[1.48223]$} & {$[0.10518]$} & {$[-0.63641]$} & {$[-1.25673]$} & {$[0.97267]$}
\end{tabular}




\begin{tabular}{lrrrrr}
\multicolumn{1}{c}{ ELE(-1) } & $\mathbf{4 . 4 4 8 5 7 9}$ & -0.084513 & 0.920601 & 57.02349 & -1.866793 \\
& $\mathbf{( 1 6 . 7 1 9 5 )}$ & $(0.08540)$ & $(1.43352)$ & $(98.8066)$ & $(2.80499)$ \\
& {$[\mathbf{0 . 2 6 6 0 7}]$} & {$[-0.98965]$} & {$[0.64219]$} & {$[0.57712]$} & {$[-0.66553]$} \\
INF(-1) & & & & & \\
& 0.303642 & -0.001218 & 0.066568 & -1.267982 & 0.060141 \\
& $(0.99623)$ & $(0.00505)$ & $(0.08605)$ & $(5.88742)$ & $(0.16714)$ \\
& {$[0.30479]$} & {$[-0.24109]$} & {$[0.77356]$} & {$[-0.21537]$} & {$[0.35982]$} \\
DPIB(-1) & & & & & \\
& 0.016023 & $5.15 \mathrm{E}-05$ & 0.000184 & -0.013022 & 0.000273 \\
& $(0.01456)$ & $(7.4 \mathrm{E}-05)$ & $(0.00125)$ & $(0.08667)$ & $(0.00244)$ \\
TIR(-1) & {$[1.10077]$} & {$[0.69831]$} & {$[0.14707]$} & {$[-0.15024]$} & {$[0.11187]$} \\
& & & & & \\
& -0.201917 & -0.000669 & -0.013113 & -0.606569 & 0.117435 \\
C & $(0.50922)$ & $(0.00258)$ & $(0.04366)$ & $(3.00944)$ & $(0.08607)$ \\
& {$[-0.39652]$} & {$[-0.25908]$} & {$[-0.30032]$} & {$[-0.20156]$} & {$[1.36441]$} \\
& & & & & \\
& -3.877344 & 0.328952 & 2.764892 & 204.2469 & 5.189543 \\
& $(16.7390)$ & $(0.08493)$ & $(1.43572)$ & $(98.9479)$ & $(2.80923)$ \\
& {$[-0.23164]$} & {$[3.87319]$} & {$[1.92579]$} & {$[2.06419]$} & {$[1.84732]$} \\
\hline \hline R-squared & 0.158937 & 0.074533 & 0.072948 & 0.103349 & 0.143392 \\
Adj. R-squared & 0.018760 & -0.079712 & -0.081561 & -0.046093 & 0.000624 \\
Sum sq. resids & 279007.9 & 7.069542 & 1948.817 & 8443645. & 7645.170 \\
S.E. equation & 96.43787 & 0.485439 & 8.059811 & 530.5232 & 15.96368 \\
F-statistic & 1.133831 & 0.483211 & 0.472126 & 0.691569 & 1.004369 \\
Mean dependent & 0.984195 & 0.305556 & 3.212414 & 208.6944 & 5.665804 \\
S.D. dependent & 97.35539 & 0.467177 & 7.749958 & 518.7037 & 15.96866 \\
\hline \hline
\end{tabular}

\section{Autocorrelation test}

\begin{tabular}{ccc}
\hline \hline Lags & LM-Stat & Prob \\
\hline \hline 1 & 53.97866 & 0.0007 \\
2 & 58.34694 & 0.0002 \\
\hline \hline
\end{tabular}

VAR (2): current expenditure

\section{$\checkmark$ Estimation}

Bayesian VAR Estimates

Date: 04/21/19 Time: 03:18

Sample (adjusted): 19832017

Included observations: 35 after adjustments

Prior type: Litterman/Minnesota

Initial residual covariance: Univariate AR

Hyper-parameters: Mu: 0, L1: 0.1, L2: 0.99, L3: 1

Standard errors in ( ) \& t-statistics in [ ]

\begin{tabular}{rccccc}
\hline \hline & C_DC & ELE & INF & \multicolumn{1}{c}{ DPIB } & TIR \\
\hline \hline C_DC(-1) & 0.119781 & $5.01 \mathrm{E}-05$ & -0.004082 & -0.582948 & 0.013279 \\
& $(0.08528)$ & $(0.00041)$ & $(0.00661)$ & $(0.49501)$ & $(0.01424)$ \\
& {$[1.40454]$} & {$[0.12165]$} & {$[-0.61720]$} & {$[-1.17765]$} & {$[0.93249]$} \\
C_DC(-2) & 0.005852 & $-4.46 \mathrm{E}-05$ & -0.001070 & -0.128493 & -0.001036 \\
& & 52 & & ISSN 1923-3981 & E-ISSN 1923-399X
\end{tabular}




\begin{tabular}{|c|c|c|c|c|c|}
\hline & $\begin{array}{l}(0.04801) \\
{[0.12189]}\end{array}$ & $\begin{array}{r}(0.00023) \\
{[-0.19298]}\end{array}$ & $\begin{array}{r}(0.00372) \\
{[-0.28804]}\end{array}$ & $\begin{array}{r}(0.27814) \\
{[-0.46197]}\end{array}$ & $\begin{array}{r}(0.00800) \\
{[-0.12943]}\end{array}$ \\
\hline ELE(-1) & $\begin{array}{l}4.635813 \\
(17.3898) \\
{[0.26658]}\end{array}$ & $\begin{array}{r}-0.091193 \\
(0.08518) \\
{[-1.07064]}\end{array}$ & $\begin{array}{l}1.108611 \\
(1.35865) \\
{[0.81596]}\end{array}$ & $\begin{array}{l}61.09119 \\
(101.682) \\
{[0.60081]}\end{array}$ & $\begin{array}{r}-1.985759 \\
(2.92510) \\
{[-0.67887]}\end{array}$ \\
\hline $\operatorname{ELE}(-2)$ & $\begin{array}{l}1.516772 \\
(9.77372) \\
{[0.15519]}\end{array}$ & $\begin{array}{r}-0.016728 \\
(0.04797) \\
{[-0.34875]}\end{array}$ & $\begin{array}{l}0.146805 \\
(0.76361) \\
{[0.19225]}\end{array}$ & $\begin{array}{l}21.02221 \\
(57.1493) \\
{[0.36785]}\end{array}$ & $\begin{array}{c}0.226136 \\
(1.64402) \\
{[0.13755]}\end{array}$ \\
\hline INF(-1) & $\begin{array}{c}0.325677 \\
(1.07564) \\
{[0.30277]}\end{array}$ & $\begin{array}{r}-0.001136 \\
(0.00523) \\
{[-0.21715]}\end{array}$ & $\begin{array}{l}0.065214 \\
(0.08465) \\
{[0.77042]}\end{array}$ & $\begin{array}{r}-1.465634 \\
(6.28952) \\
{[-0.23303]}\end{array}$ & $\begin{array}{c}0.070890 \\
(0.18094) \\
{[0.39179]}\end{array}$ \\
\hline $\operatorname{INF}(-2)$ & $\begin{array}{c}0.352837 \\
(0.60420) \\
{[0.58397]}\end{array}$ & $\begin{array}{c}0.000680 \\
(0.00294) \\
{[0.23133]}\end{array}$ & $\begin{array}{r}-0.024652 \\
(0.04764) \\
{[-0.51748]}\end{array}$ & $\begin{array}{c}0.010068 \\
(3.53291) \\
{[0.00285]}\end{array}$ & $\begin{array}{l}0.022130 \\
(0.10163) \\
{[0.21774]}\end{array}$ \\
\hline $\operatorname{DPIB}(-1)$ & $\begin{array}{l}0.015922 \\
(0.01478) \\
{[1.07731]}\end{array}$ & $\begin{array}{c}4.98 \mathrm{E}-05 \\
(7.2 \mathrm{E}-05) \\
{[0.69370]}\end{array}$ & $\begin{array}{l}0.000189 \\
(0.00115) \\
{[0.16348]}\end{array}$ & $\begin{array}{r}-0.016441 \\
(0.08708) \\
{[-0.18880]}\end{array}$ & $\begin{array}{c}0.000208 \\
(0.00249) \\
{[0.08355]}\end{array}$ \\
\hline $\operatorname{DPIB}(-2)$ & $\begin{array}{r}-2.85 \mathrm{E}-05 \\
(0.00816) \\
{[-0.00349]}\end{array}$ & $\begin{array}{r}-9.12 \mathrm{E}-06 \\
(4.0 \mathrm{E}-05) \\
{[-0.22993]}\end{array}$ & $\begin{array}{c}2.80 \mathrm{E}-05 \\
(0.00064) \\
{[0.04388]}\end{array}$ & $\begin{array}{r}-0.012843 \\
(0.04817) \\
{[-0.26662]}\end{array}$ & $\begin{array}{c}1.55 \mathrm{E}-05 \\
(0.00137) \\
{[0.01131]}\end{array}$ \\
\hline $\operatorname{TIR}(-1)$ & $\begin{array}{r}-0.204688 \\
(0.51202) \\
{[-0.39977]}\end{array}$ & $\begin{array}{r}-0.000709 \\
(0.00249) \\
{[-0.28462]}\end{array}$ & $\begin{array}{r}-0.009975 \\
(0.04000) \\
{[-0.24934]}\end{array}$ & $\begin{array}{r}-0.561393 \\
(2.99394) \\
{[-0.18751]}\end{array}$ & $\begin{array}{c}0.111643 \\
(0.08678) \\
{[1.28649]}\end{array}$ \\
\hline $\operatorname{TIR}(-2)$ & $\begin{array}{c}0.024614 \\
(0.28393) \\
{[0.08669]}\end{array}$ & $\begin{array}{c}0.000122 \\
(0.00138) \\
{[0.08812]}\end{array}$ & $\begin{array}{c}0.000116 \\
(0.02218) \\
{[0.00521]}\end{array}$ & $\begin{array}{l}0.288273 \\
(1.66022) \\
{[0.17364]}\end{array}$ & $\begin{array}{l}0.015213 \\
(0.04821) \\
{[0.31556]}\end{array}$ \\
\hline $\mathrm{C}$ & $\begin{array}{r}-5.383844 \\
(17.9020) \\
{[-0.30074]}\end{array}$ & $\begin{array}{c}0.344397 \\
(0.08713) \\
{[3.95266]}\end{array}$ & $\begin{array}{l}2.349021 \\
(1.39926) \\
{[1.67876]}\end{array}$ & $\begin{array}{l}201.5539 \\
(104.709) \\
{[1.92489]}\end{array}$ & $\begin{array}{c}5.274495 \\
(3.01256) \\
{[1.75084]}\end{array}$ \\
\hline $\begin{array}{l}\text { R-squared } \\
\text { Adj. R-squared } \\
\text { Sum sq. resids } \\
\text { S.E. equation } \\
\text { F-statistic } \\
\text { Mean dependent } \\
\text { S.D. dependent }\end{array}$ & $\begin{array}{r}0.174105 \\
-0.170018 \\
273745.2 \\
106.7991 \\
0.505938 \\
1.455422 \\
98.73505\end{array}$ & $\begin{array}{r}0.093097 \\
-0.284779 \\
6.840639 \\
0.533879 \\
0.246369 \\
0.314286 \\
0.471008\end{array}$ & $\begin{array}{r}0.098664 \\
-0.276893 \\
1726.461 \\
8.481502 \\
0.262713 \\
2.827460 \\
7.505774\end{array}$ & $\begin{array}{r}0.126589 \\
-0.237332 \\
8217586 . \\
585.1491 \\
0.347848 \\
211.2543 \\
526.0456\end{array}$ & $\begin{array}{r}0.152015 \\
-0.201312 \\
7490.059 \\
17.66595 \\
0.430238 \\
5.936256 \\
16.11792\end{array}$ \\
\hline
\end{tabular}

\section{$\checkmark$ Autocorrelation test}

\begin{tabular}{ccc}
\hline \hline Lags & LM-Stat & Prob \\
\hline \hline 1 & 69.73856 & 0.0000 \\
2 & 63.30596 & 0.0000 \\
\hline \hline
\end{tabular}

